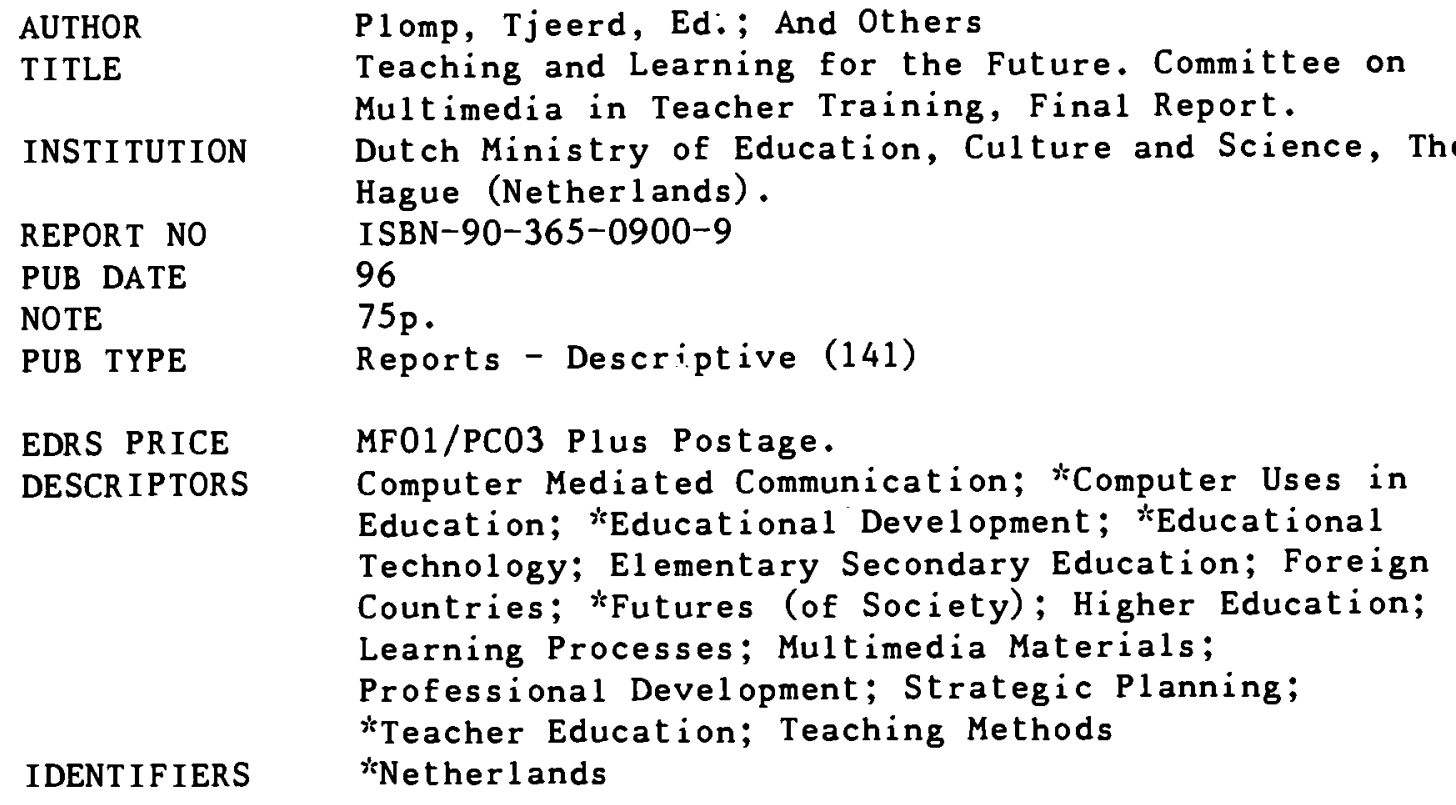

\title{
ABSTRACT
}

This is the final report of the Committee on Multimedia in Teacher Training (COMMITT), which offers a strategic framework to support efforts of teacher training institutes in the Netherlands to develop their own plans for enhancing the teaching and learning process as well as its outcomes through the application of Information and Communication Technology (ICT). The purpose of the plan of action, called "a leap for the future," is to serve as a catalyst for teacher training institutes, elementary and secondary schools, and universities to work together on a common goal: improving teaching and learning through the application of ICT. This report consists of seven chapters. The first chapter is an introduction to the initiative to revitalize teacher training and the committee's activities. Chapter 2 describes an analysis of the transformation of society and consequences for learning in the future. Chapter 3 discusses key elements in the teaching and learning process. A conceptual model is presented which serves as a frame of reference for COMMITT. The role of ICT in teaching and learning is also discussed. Chapter 4 out 1 ines the scope of COMMITT and provides examples illustrating the impact of ICT as a medium for education. Chapter 5 describes the challenges, opportunities and possible threats of implementing ICT in the education system and teacher training institutes. Guidelines for a program of action are elaborated in Chapter 6 . The role of government, vision underlying the program, strategy and program of action, management and organization, and budget are discussed. Chapter 7 includes concluding remarks with a special emphasis on issues and factors which are expected to influence the implementation of the "leap for the future." Appendices present a 1 ist of the COMMITT members; a discussion on the Dutch education system; Committee statements; statements developed and judged by ICT coordinators; and different types of use of ICT as a medium. (AEF) 


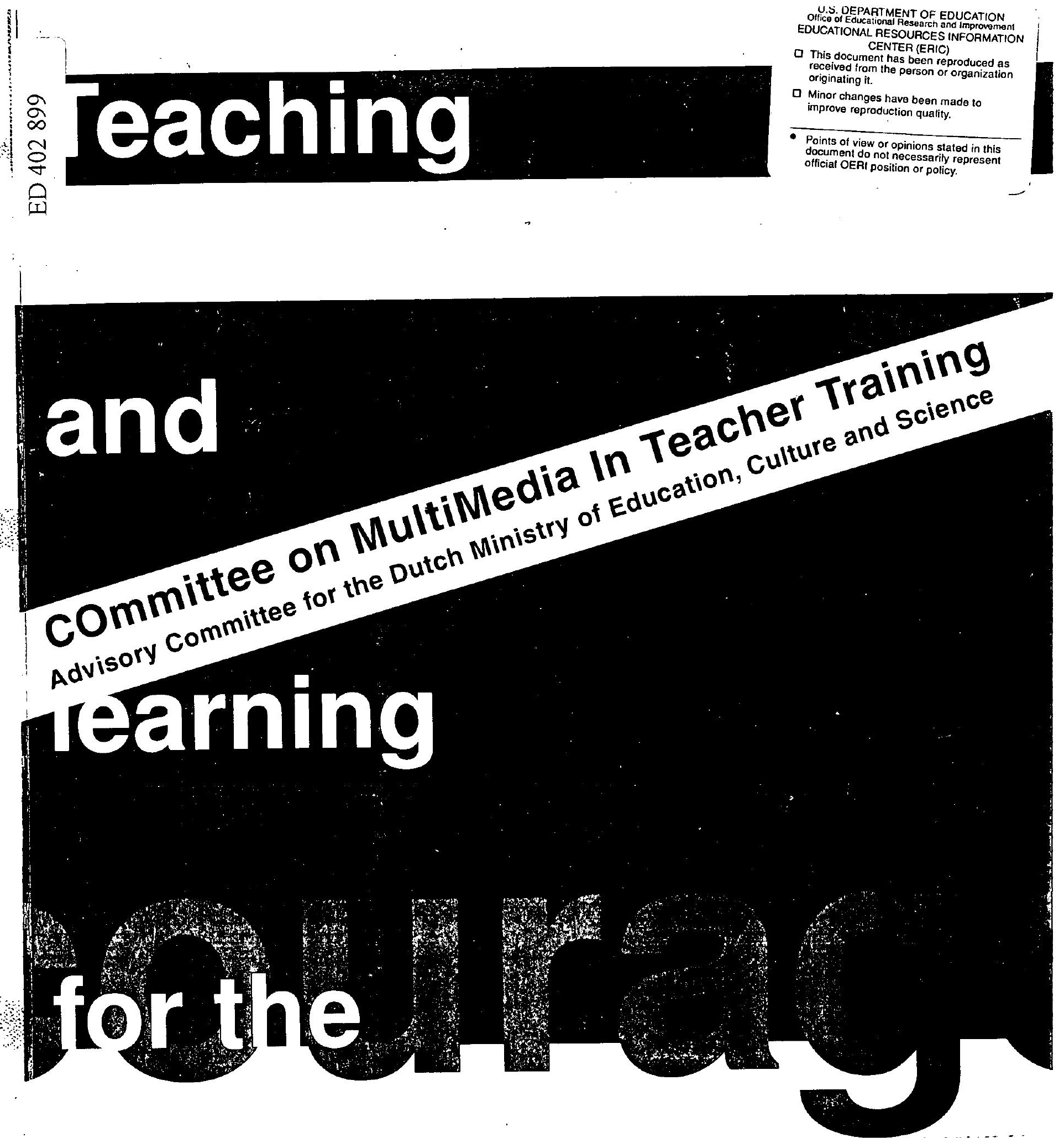

"PERMISSION TO REPRODUCE THIS MATERIAL HAS BEEN GRANTED BY

Tjeerd Plomp

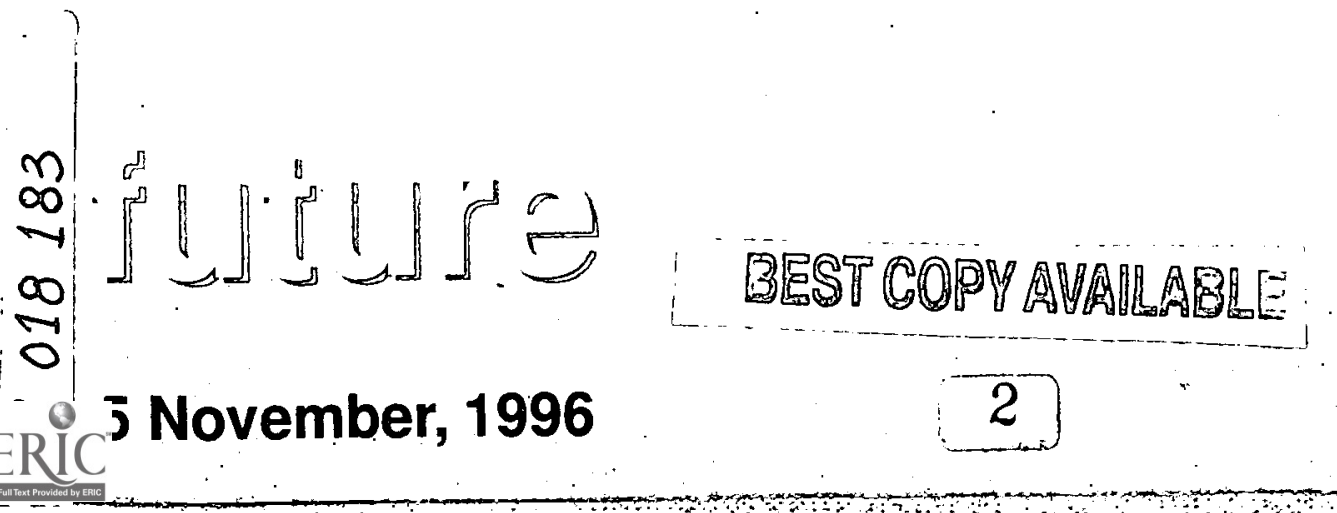

TO THE EDUCATIONAL RESOURCES INFORMATION CENTER (ERIC)."

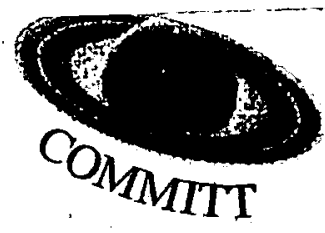




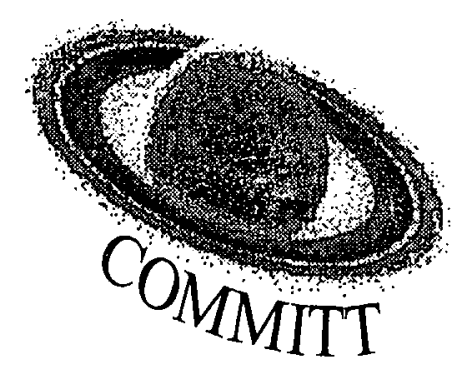

\section{Teaching and learning for the future}

prepared by COMMITT (Eds. Tj. Plomp, A. ten Brummelhuis, \& R. Rapmund) Committee On MultiMedia In Teacher Training

Advisory committee established by the Dutch Minister of Education

Secretariat COMMITT

University Twente

P.O. box 217

7500 AE Enschede

The Netherlands

e-mail: committ@edte.utwente.nl

WWW: http://www.to.utwente.nl/prj/committ 
Teaching and learning for the future

COMMITT (Eds.: Tj. Plomp, A. ten Brummelhuis, \& R. Rapmund)

Report of the Committee On MultiMedia In Teacher Training. - With ref. - With summary in Dutch.

Subject headings: Information and Communication Technology - teacher training - innovation - program of action.

Cover design: Marita Wesselink

Press: $\quad$ PrintPartners Ipskamp, Enschede

Price: $\quad$ Fl. 12,50

Copies of this report can be ordered by mail or telephone via the address below, with reference to the ISB-number.

Exemplaren van deze publikatie zijn schriftelijk of telefonisch te bestellen bij de afdeling Verkoop Sdu DOP, onder vermelding van het ISB-nummer.

Afdeling Sdu DOP

Postbus 30405

2500 GK DEN HAAG

Tel: (070) 3789830

Fax: (070) 3789783

ISBN 90-365-0900-9 


\section{Samenvatting}

De internationale adviescommissie 'Committee On MultiMedia In Teacher Training' (COMMITT) is door de Nederlandse minister van Onderwijs, Cultuur en Wetenschappen ingesteld voor advies over de leeromgeving van de toekomst en de rol van Informatie- en Communicatie Technologie (ICT) ter ondersteuning van het leerproces, met name in de lerarenopleidingen. De adviescommissie is ook gevraagd concrete voorstellen te doen over regionaal op te zetten innovatiecentra voor de begeleiding van de verdere invoering van ICT. In februari 1996 is een concept van het referentiekader voor de uitwerking van de opdracht gepubliceerd. Een stand-van-zaken rapport verscheen in mei 1996. Voor u ligt het eindrapport van de commissie. Het advies aan de minister heeft niet zozeer het karakter van een enkelvoudig aktiviteitenplan, maar wordt gekenmerkt door een conceptueel en strategisch kader voor de toekomstige leeromgeving van lerarenopleidingen en scholen. Dit kader biedt de mogelijkheid plannen te ontwikkelen om zowel de kwaliteit van onderwijzen en leren als de resultaten daarvan te verhogen met behulp van ICT. In deze benadering wordt overheidssteun beschouwd als een katalysator voor verandering en als aansporing voor lerarenopleidingen en scholen om ICT in het curriculum op te nemen. Een belangrijk uitgangspunt van het aktieprogramma, 'Een sprong naar de toekomst' ('A leap for the future') geheten, is de samenwerking tussen enerzijds lerarenopleidingen en anderzijds scholen voor primair en secundair onderwijs met als gemeenschappelijk beoogd doel: het verbeteren van onderwijzen en leren door de toepassing van ICT.

Het werk van de adviescommissie startte met de ontwikkeling van een visie op de samenleving als geheel en de veranderingen daarin, het schetsen van een algemeen kader dat ten grondslag ligt aan de inrichting van onderwijsleerprocessen en het aangeven van de rol die ICT daarbinnen kan vervullen.

Zoals in het rapport beschreven, ondergaat onze samenleving op het moment een transformatie van een industriële samenleving naar een informatiemaatschappij. Het onderwijs van vandaag wordt uitgedaagd om mensen voor te bereiden voor een samenleving waarin het adequaat kunnen omgaan met informatie tot één van de belangrijkste activiteiten behoort. Daarnaast wordt van het onderwijs ook verwacht dat zij (a) bijdraagt aan de oplossing van maatschappelijke vraagstukken op sociaal, economisch en cultureel terrein, (b) geïndividualiseerd en flexibel onderwijs aanbiedt dat tegemoet komt aan specifieke behoeften en (c) verandert in de richting van levenslang leren en meer tegemoet komt aan leerlinggeörienteerde vormen van onderwijs.

Onderwijzen, en in het bijzonder de inrichting van leerprocessen, kan beschreven worden aan de hand van een functioneel model in termen van sturende krachten die er op van invloed zijn. Ten eerste is dat de relatie tussen de actoren van het leerproces: de leraar en de leerling. Ten tweede is er de infrastructuur, bestaande uit leerinhouden, onderwijs- en leermaterialen en de technische infrastructuur. Het leerproces vindt plaats op het kruisvlak van beide genoemde dimensies. Op grond van de uitdagingen waar het onderwijs voor staat in het kader van een veranderende maatschappij is de verwachting dat de inrichting van leerprocessen zal verschuiven van vooral leerkracht geörienteerd naar meer leerling gestuurd. ICT biedt mogelijkheden om deze ingrijpende veranderingen te faciliteren. Echter, het plaatsen van een aantal computers in scholen (een verandering van één element van het functioneel model, namelijk de technische infrastructuur) zal niet noodzakelijkerwijs leiden tot veranderingen in 
de andere sturende krachten, laat staan leiden tot verbetering van het leerproces. Om in een meer leerling gestuurde inrichting van leerprocessen zoveel mogelijk te kunnen profiteren van de potentiële mogelijkheden die nieuwe technologieën kunnen bieden, is het nodig om veranderingen door te voeren in zowel de rollen van leraar en leerling, als de leerinhouden en de daarmee samenhangende leermaterialen. Dit dient in onderlinge samenhang te gebeuren.

Deze visie wordt gereflecteerd in het aktieprogramma dat de adviescommissie voorstelt. Dit aktieprogramma, 'Een sprong naar de toekomst', bestaat niet uit een enkelvoudig recept voor integratie van ICT in de lerarenopleidingen en scholen. Het is een programma gericht op effectief gebruik van technologie voor onderwijsdoeleinden waarbij de lerarenopleidingen een centrale rol is toegedacht. Dit is een belangrijke uitdaging aan het adres van deze opleidingen. In de visie van de commissie zijn de aard en omvang van het gebruik van technologie niet een zaak van ontwerp door overheid of onderwijsdeskundigen, maar het resultaat van samenwerking tussen krachten die kunnen worden aangeduid met 'top-down' (bijvoorbeeld de overheid) en 'bottom-up' (bijvoorbeeld de lerarenopleidingen). Het aktieprogramma is gebaseerd op een samenwerkingsmodel dat essentieel is voor een duurzame verbetering van de inrichting van onderwijsleerprocessen. Zakenleven, overheid en onderwijs hebben hierin allen iets unieks en waardevols in te brengen en een ieders expertise en hulpmiddelen dienen in het programma samengebracht worden.

Het doel van het programma is om zichtbaar te maken op welke wijze ICT nieuwe manieren van onderwijzen en leren kan ondersteunen en op welke wijze studenten van de lerarenopleiding voorbereid kunnen worden op een toekomst waarin dergelijke leerprocessen in primair en secundair onderwijs plaats vinden. Er zijn veel kansen voor de lerarenopleidingen om aan het programma bij te dragen.

Teneinde studenten van de lerarenopleidingen voor te bereiden op het toekomstige onderwijs, moeten de lerarenopleidingen hun focus verschuiven van het bedienen van het huidige onderwijs naar het bedienen van wat zich aandient als 'het onderwijs van de toekomst'. Zij zullen zowel ruimte als kansen moeten scheppen in hun onderwijsprogramma om een dergelijke transformatie mogelijk te maken. Dit brengt een dilemma met zich mee omdat de lerarenopleidingen het huidige onderwijs natuurlijk niet kunnen negeren. Volgens COMMITT ligt de oplossing voor dit dilemma in het onderscheiden van een transitie-periode tussen de huidige situatie en de situatie waarin het onderwijs zijn nieuwe vorm zal hebben gekregen. In deze transitie-periode wordt de ontwikkeling van 'het nieuwe' versterkt, terwijl 'het oude' nog steeds bestaat. Gedurende dit proces heeft 'het oude' zorg en aandacht nodig, maar mag de groei van 'het nieuwe' niet belemmeren. 'Het oude' zou uitgedaagd moeten worden om in 'het nieuwe' op te gaan, maar tegelijkertijd dient 'het nieuwe' voortdurend gestimuleerd te worden.

De transitie-periode kan dus samengevat worden in termen van zowel zorg als durf: zorg voor de bestaande onderwijspraktijk en durf om de nieuwe inrichting van leerprocessen te verkennen en vorm te geven. Het aktieprogramma creëert kansen voor nieuwe definities van onderwijs en daagt lerarenopleiders en leerkrachten uit daaraan deel te nemen. Centraal in het programma staat het genereren en ondersteunen van 'emergent practices' ('opkomende praktijken') in lerarenopleidingen en het voorbereiden van studenten voor 'opkomende praktijken' in het primair en secundair onderwijs.

Het aktieprogramma omvat de volgende elementen: training, 'connectivity', uitdagingen, centra voor onderwijstechnologie, 'emergent practice' projecten, een instituut voor een 
experimentele lerarenopleiding, monitoring, reflectie en onderzoek. Het programma moet niet beschouwd worden als een keuze-menu waaruit een enkel element kan worden geselecteerd. Het programma geeft een integrale benadering weer, dat een daarop gerichte managementstructuur vergt, zowel op beleids- als op uitvoerend niveau. Het management van het programma dient onafhankelijk te zijn van instituutsbelangen. Het voorstel omvat een opzet voor het bestuur en het uitvoerend management en bevat tevens een berekening van de met de uitvoering van het programma samenhangende kosten voor een periode van 7 jaar. Het programma moet afgestemd worden op andere ontwikkelingen in de lerarenopleidingen, die worden aangestuurd door het 'Procesmanagement Lerarenopleidingen' (PML). Als voorbeeld kan genoemd worden dat het nieuwe kerncurriculum voor de lerarenopleiding de aanbevelingen van COMMITT zou moeten reflecteren.

Om ervan verzekerd te zijn dat er een degelijke kennisbasis ontstaat ter ondersteuning van de inspanningen van lerarenopleidingen en scholen, zouden universiteiten en onderzoekcentra aktief betrokken moeten zijn bij onderzoek op dit terrein. Deze onderzoeksinspanningen dienen afgestemd te worden op het aktieprogramma 'Een sprong naar de toekomst'. Onderzoekers zullen, om voor financiering uit het aktieprogramma in aanmerking te komen, moeten samenwerken met lerarenopleidingen en scholen voor primair en secundair onderwijs en onderzoek moet gericht zijn op de kernthema's van het aktieprogramma. Onderzoek naar de voortgang van het proces en verspreiding van ervaringen zullen bijdragen aan een helder beeld van zowel de lerarenopleiding als de onderwijspraktijk van de toekomst. 


\section{Executive summary}

The Committee On MultiMedia In Teacher Training (COMMITT) has been established by the Dutch Minister of Education to draw up recommendations on the design of the learning process of the future and the role of Information and Communication Technology (ICT) to support the learning process, with a focus on teacher training. The committee has been asked in particular to put forward concrete proposals for the setting up of regional innovation centres to support the integration of ICT in the learning process. The first paper of the committee was a discussion paper including a draft for a frame of reference for the committee's work (COMMITT, discussion paper, February 1996). The second paper (COMMITT, interim report, May 1996) was a report about the status of the committee's progress halfway its work. This is the final report, which does not merely include a plan of action. Instead, it offers a strategic framework to support efforts of teacher training institutes and their teachers to develop their own plans for enhancing the teaching and learning process as well as its outcomes through the application of ICT. In this approach the support of the government is intended as a catalyst for change and for providing incentives for both teacher training institutes and schools to integrate ICT in the curriculum. The purpose of the plan of action, called 'a leap for the future', is to serve as a catalyst for teacher training institutes, schools for primary and secondary education and universities to work together on a common goal: improving teaching and learning through the application of ICT.

The committee's work started with the development of a vision on the society at large and the changes that take place, the teaching and learning process within this society and the role ICT could play within education. As the report describes, our society is currently transforming from an industrial society into an information society. Today's education system faces the challenge to prepare individuals for the information society in which one of the most important aims is to handle information. Beside the challenge of preparing individuals for the information era, the education system is also facing challenges as (a) the expectation that education contributes to the solution of social, cultural and economical problems of society, (b) people wishing education to be individualised and flexible, suited to their specific needs and (c) the change towards life-long learning and new demands for learning.

Education, or more specifically the learning process, can be described in terms of the driving forces behind this process. First there is the relation between the actors in the learning process: the teacher and the learner or student. Secondly the learning infrastructure, consisting of content, teaching and learning materials and technical infrastructure, plays a role. The learning process takes place at the cross section of these dimensions. Based on the challenges and expectations toward the education system, it is assumed that a shift from teacher oriented arrangements of the learning process towards more student oriented arrangements will be necessary. ICT provides a means to facilitate and instrument these revolutionary changes called for by the transitions in society. As a tool to support the learning process ICT holds a promise of new solutions for the challenge that education is facing. But changing just one of the driving forces in the learning process does not necessarily lead to substantial changes and improvement of the learning process as a whole. Only in conjunction with changes in the roles of the teacher and the student, and with changes in the organisation of the content and corresponding curriculum materials, is it possible to make use of the potentials the technology has to enhance the learning process in a way that society is asking for. 
This integrated approach is reflected in the committee's program of action. The program of action, called 'A Leap for the Future' does not include a mere 'formula' for integrating technology into the classroom and school curriculum. The program, covering a seven-year period, focuses on the effective use of technology with a central role for teacher training institutes. This is a major challenge for these institutes. The nature and level of technology use is not a matter of design by government or by educational experts but is a matter of cooperation between forces from bottom-up (such as the government) and top-down (such as the teacher training institutes). The program is based on a collaborative model which is essential for sustained improvement of the arrangement of the teaching and learning process. Government, education and business all have something unique and valuable to offer. The purpose is to demonstrate new models of how an information infrastructure can be beneficial for teaching and learning and how to prepare student teachers for arranging the future learning process. The program asks for collaborative efforts, efforts in which multiple organisations pool their expertise and resources. There are many opportunities for teacher training institutions to contribute to the program.

In order to prepare student teachers for future education, the current teacher training institutes should shift their focus from serving the current education to serving what emerges as the education of the future. They have to create both space and opportunities in their program for such a transformation. This causes a dilemma, as teacher training institutes cannot refrain completely from providing the current education system with teachers who can function in the existing situation. According to COMMITT, the solution for this dilemma is to distinguish a transition period first, covering the time span from our current situation to the situation in which education will get its new shape. This implies strengthening the development of something 'new', while 'old' still exists. During the transition process 'old' needs care and attention, but should not prevent 'new' from growing. 'Old' should be challenged to 'emerge into new' but at the same time, 'new' needs stimulation and incentives. Thus, the transition period can be summarised in terms of both care and courage; care for the existing practices and courage to explore and start a new arrangement of the learning process. The proposed program of action is aiming at a transition period which has to provide bridges from 'old' to 'new'. The program creates opportunities for new definitions of education and at the same time challenges educators from existing practices to participate. One of the main activities in this transition period is to generate and support 'emergent practices' in teacher training institutes as well as to prepare student teachers for 'emergent practices' in primary and secondary education.

The program of action includes the following elements: training, 'connectivity', challenges, centres for learning technology, emergent practice projects, an institute for experimental teaching education, monitoring, reflection and research. This program cannot be perceived as a menu from which only some elements may be selected. The program reflects an integral approach which asks for an appropriate management structure on both policy level and executive level for the duration of the program. The management at the executive level should be independent from the institutional interests. A proposal for an administrative and managerial structure for the program as well as the calculations for the finances are included for a period of seven years. The program has to be attuned to other innovations in teacher training, managed by the 'process management for teacher training (PML)'. For example, the new core curriculum for teacher training should reflect the recommendations of COMMITT. 
Universities and research centres have to be engaged in research on the use of technology in education to ensure an adequate knowledge base to guide school efforts. To ensure that research addresses critical issues, the research activities have to be integrated in and attuned to the action program 'A Leap for the Future'. Researchers must collaborate with teacher training institutes and schools for primary and secondary education to focus on key issues. Monitoring the process and dissemination of the first hand experiences will create a clear picture of both tomorrow's teacher training and the educational practices in the field for which teachers are being prepared. 


\section{Preface}

The task that the Committee On MultiMedia In Teacher Training (COMMITT) received from Minister Ritzen of Education, Culture and Science is not only important, but has a special character as well. It illustrates the importance the Dutch Government attaches to Information and Communication Technology (ICT) in preparing education for the information society. The special character of COMMITT is reflected in the assignment to develop proposals for the integration of ICT in the new core curricula of the teacher training institutes in the Netherlands. This endeavour is not only new for the Netherlands, but it is also in international perspective an illustration of 'courage' to develop such new arrangements of teaching and learning, preparing teachers for the society of the future.

The central goals of the process of change of teacher training in the Netherlands are enhancing the quality of education and increasing its efficiency. ICT, if properly integrated, can provide an important contribution to the realisation of these goals. This approach reflects an important starting point for COMMITT: the use of ICT is not a goal in itself, but should be based on a vision related to the society of the future, the mission of education and the arrangement of the teaching and learning process.

One of the basic principles underlying the proposed program of action is that both 'care' and 'courage' are needed to succeed in the complex and difficult process of change: care for the existing practices and courage to explore new arrangements of teaching and learning. Part of the care is the need for lifelong professionalisation of teachers and managers, both in schools and in teacher training institutes.

Thanks have to be conveyed to the international members of COMMITT; their names and addresses are included in Appendix 1. Studying and reflecting on the role of ICT in education is a concern and an interest of many societies, despite all the differences in 'education cultures'. Working on this advisory report in an international context has been an inspiring experience. International co-operation should not be restricted to the advisory part of this innovation process, but should be continued in its execution phase as well. Countries can learn from each others' experiences, from their successes and failures. This is the reason why this report is written in English.

We are grateful to the national ICT experts, managers and ICT co-ordinators of teacher training institutes in the Netherlands who provided important input to our work. The discussions with them stimulated the thinking of the committee and are reflected in this report.

Special acknowledgements go to Ingeborg Janssen Reinen (University of Twente) who acted as a committed and 'critical friend' in the writing of this report, to Sandra Schele for secretarial support, to Marita Wesselink for the graphical design of the cover, and to the printer, who was willing to print this report during the weekend of celebrating the opening of their new building.

Finally, we hope that this advice may contribute to policy making regarding the future of teacher training, and especially the role of ICT to enhance the teaching and learning process and the quality of education.

Prof.dr. Tjeerd Plomp

(chairman COMMITT) 


\section{Table of contents}

\section{Introduction}

1.1 The initiative to revitalise teacher training 1

1.2 The committee's activities 3

1.3 Structure of this report 4

2 Society at large: a frame of reference $\quad 7$

$\begin{array}{ll}2.1 \text { Transformation of society } & 7\end{array}$

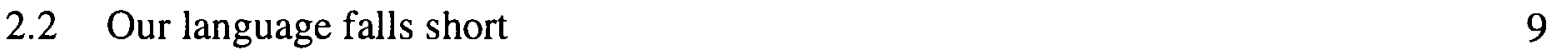

2.3. A systems view 9

3 The learning process and Information and Communication Technology 13

$\begin{array}{lll}3.1 & \text { The learning process } & 13\end{array}$

3.2 Two approaches: teacher oriented and student oriented 14

$\begin{array}{ll}\text { 3.3 The role of ICT in the teaching and learning process } & 16\end{array}$

4 The scope of COMMITT $\quad 19$

$\begin{array}{lll}4.1 \text { The focus } & 19\end{array}$

4.2 Phases of use: an implementation perspective 19

4.3 Examples illustrating the impact of ICT as a medium for education 21

5 Future educating. 25

5.1 In search of a new balance 25

$\begin{array}{ll}5.2 & \text { Challenges for the education system } \\ 5.3 & 25\end{array}$

5.3 Challenges for the teacher training institutes 26

$\begin{array}{ll}5.4 & \text { Problems and possible threats of ICT implementation }\end{array}$

6 A leap for the future $\quad 29$

6.1 Reflecting the role of government 29

$\begin{array}{ll}6.2 & \text { Vision underlying the program of action } \\ 6.3 & 30\end{array}$

6.3 Strategy and design: riding the waves between care and courage 31

6.4 A program of action 33

$\begin{array}{ll}6.5 & \text { Management and organisation } \\ 6.6 & 37\end{array}$

$\begin{array}{lll}6.6 \text { Budgets } & 40\end{array}$

$\begin{array}{lll}7 & \text { Concluding remarks } & 47\end{array}$

\section{References}

Appendices

appendix 1: COMMITT: members of the committee

appendix 2: The Dutch education system

appendix 3: Committee statements

appendix 4: Statements developed and judged by ICT co-ordinators

appendix 5: Different types of use of ICT as medium 


\section{Introduction}

\subsection{The initiative to revitalise teacher training}

At this time, educational policy in the Netherlands focuses on a number of issues:

- broadening and integrating educational care in primary education, countering trends towards more and more specialisation for children with special needs (the 'back to school together again' policy);

- renewal of the second phase of secondary education, aiming to give students more responsibilities for their learning; for instance in 'study houses' instead of classrooms;

- enhancing 'succeedability' of higher education, improving the critical, non-individual success-factors that determine whether or not a higher education program can be finished successfully.

Beside these issues, the implementation of Information and Communication Technologies (ICT) has been an important policy issue for more than ten years. Computers and educational software have been introduced at all levels of education. Large scale training and development projects have been undertaken to increase the level of competence of teachers.

In all those years of ongoing efforts to modernise the education system, until recently no special attention was given to teacher training. In the summer of 1995, the Dutch Minister of Education sent a report to the Parliament about the necessity of revitalising teacher training (Ministry of Education, Vitale Lerarenopleidingen, 1995). The developments in the application and dissemination of knowledge and information technology have been changing the demands in education. It was felt that teacher training is a crucial factor in meeting these demands, but at the same time that the teacher training institutes needed to be reformed. Four goals were set:

1. The development of a common core curriculum for both primary and secondary education teachers.

2. The formation of regional centres for co-operation in teacher training.

3. The enhancement of human resource management.

4. The establishment of innovation centres for ICT.

The committee has no specific data available on the current use of ICT in teacher training. The government report mentioned above describes the situation of teacher training institutes in general terms.

The Council for Higher Education (the representative body of all institutes for higher professional education, including the teacher training institutes; see Appendix 2) agreed with the findings of the report. The Council and the Ministry of Education decided to combine their efforts and jointly established a committee to manage the process of change. This committee, the so-called 'Process Management for teacher training (PML)' formulated eight basic statements that form the starting point for the process of change(PML, 1996):

- the continuous importance of basic education, professional training and adult education for a majority of the young people;

- teacher training is essential because it provides education to future educators;

- in education the focus shifts from instruction to learning-to-learn;

- schools are changing from traditional to functional organisations; 
- information and communication technologies are emerging;

- there is a need to find a balance between supply and demand in teacher training;

- a critical mass for teacher training should be created as a base for quality, efficiency and innovative potential;

- people should be prepared for mutual professional collaboration.

Based upon these statements, the PML has drawn up a plan of action, with concrete propositions for establishing regional centres for teacher training, the development of a common curriculum and a procedure for innovation projects. The relations with schools for primary and secondary education will be strengthened and improvements in in-service training will take place. PML intends to involve, beside the teacher training institutes, the other organisations involved with teacher training in this process of change. Examples of such organisations are the university teacher training institutes, research organisations, and the educational support institutes. The PML-scope for this change process is ten years. Towards the end of this period the new educational infrastructure should be established, with all organisations co-operating closely and in a coherent way. By that time, expert centres at national level and innovation centres at regional level should have been founded.

In order to succeed in the general aim to revitalise teacher training, it is expected that ICT will play a crucial role. Therefore, the Dutch Minister of Education established an advisory committee, complementary to the PML, to draw up recommendations on the role of ICT in the future functioning of teachers for which teacher training institutes have to prepare nowadays. The establishment of an international committee of experts demonstrates not only the special interest of information and communication technologies in the future of teacher training, but also that, given the 'global' character of the technological developments, this issue should be discussed in an international context. In the assignment for the 'advisory Committee On MultiMedia In Teacher Training' (COMMITT) the Minister of Education stressed that the attention should be focused on the learning environment of the future (instead of the subject 'informatics') and, as a consequence, on the way the learning process should be organised. In the report on revitalising teacher training, the Minister proposes seven innovation centres, where education of the future should be established. These centres are to be involved in the education of primary and secondary education teachers, the dissemination of expertise towards teacher trainers, schools and teachers in order to promote that teachers will use ICT in their practice. The minister wants to take a large step forward with a concentrated effort of expertise development. The international committee is expected to put forward a thorough, visionary advice regarding the learning environment of the future and the role ICT could play in this.

The name of the advisory group 'Committee On MultiMedia In Teacher Training' has given rise to some misunderstanding. The word multimedia was used because it made a nice acronym, but the committee had no intention to limit to or even to emphasise multimedia. 'Information and Communication Technologies' would have been a better term to reflect the focus of the committee. The members and representation of the committee are listed in Appendix 1.

Reflecting upon the assignment in one of his speeches for an audience of educators, the chairman of COMMITT looked back upon ten years of government policy related to information and communication technologies in education. He distinguished different uses of 
ICT in education and pointed out that ICT as object of a course and as aspect of professions is well established during this period. But ICT as a medium of learning is not. In the past ten years not many teachers have been keen to implement ICT in their teaching. And those who have implemented it, stay mainly on the safe side, substituting books with discs for example. ICT can change the teaching profession and it is important that this issue is addressed in teacher training. Teachers should be prepared to take full advantage of the potentials of ICT, but not for the sake of technology itself. COMMITT should take the learning process as the central focal point and investigate what ICT has to offer teachers and learners. Besides that, the focus should lie on the learning processes of the future, not on these of the past or even of today. And if we read the signs correctly, the future of education will be quite different from today, although it is hard to imagine what the future will hold. This is a tough challenge for the teacher training institutes, but one they cannot escape from. COMMITT will not make the challenge easier, on the contrary probably, but can and will try to decipher what questions and dilemmas lie ahead. This report will not provide a mere answer to these questions, it offers a strategic framework and a plan of action to encourage teacher training institutes, schools and people involved in the teaching and learning process to start thinking about and develop the teaching and learning of the future.

Although the assignment of COMMITT focuses on the teacher training sector, the vision of the committee on the role of ICT in education also holds when it comes to primary and secondary education and to in-service training of teachers. This means that the role of ICT in teacher training should be considered in a larger perspective, including the other educational fields.

\subsection{The committee's activities}

Based upon discussions with educators and experts from different fields, literature surveys and 'surfing Internet', the committee developed her vision on the role of ICT in education of the future. The members of the committee made comments on draft papers and on several occasions drafts were presented and discussed with teachers and administrators of teacher training institutes, both in national and international contexts. The committee held two international meetings: In May 1996 the outlines and direction of the recommendations were discussed and in October 1996 the draft version of the final report was reviewed. Both times the committee took the opportunity to discuss its findings with teacher training and educational ICT representatives. During the meeting in May a set of statements was developed covering the following four domains: the learning process and ICT, institutional conditions, professional teacher development and ICT, and the role of the government (see Appendix 3). These statements guided the discussions and further work of the committee. During the October-meeting small working of ICT co-ordinators of the Dutch teacher training institutes came up with a number of recommendations regarding the pre-final version of the report. These recommendations resulted in 25 statements, which were judged on a 5-point scale by the ICT-co-ordinators. During a subsequent meeting, the results were discussed with the managers of the teacher training institutes. An overview of the statements and the results are included in Appendix 4.

Members of the committee undertook two short study trips, one to the USA and one to the UK, in order to visit 'promising emergent practices of ICT'. In the USA 'the learning technology centre' of Peabody College at VanderBilt University provided such an example, as 
well as Northbrook Middle School in Houston and several places in and around Boston. In the UK a visit was paid to the National Council of Educational Technology (the organisation of Margaret. Bell, a member of COMMITT), some of the schools NCET co-operates with, Ultralab (the learning technology centre of Anglia Polytechnic in Anglia near London), and the Teacher Training Department of the Open University. The visits broadened the view of the committee and showed some of the important practical issues that are related to using, or beginning to use ICT in education. The findings of both trips are assimilated in the final report.

The committee would not have been able to do their work without the meaningful support of many people involved in the field of education and ICT. They put a lot of effort in the discussion of previous versions of the report, either by e-mail or in personal meetings. We thank them all for their contribution. A special word of thanks goes to some people of the faculty of Education at the University of Twente: Ingeborg Janssen Reinen for her substantial commentary on the draft versions, Bert Moonen for his contribution to the literature review, Arjan Schipper for the technical assistance in keeping the website in good condition and Sandra Schele for her secretarial support.

\section{COMMITT on WWW}

In order to inform anyone who is interested in the field of ICT in education, the committee set up a WWW-site (http://www.to.utwente.nl/prj/committ) on which the first and second report as well as other information of the committee's work could be found. From 5 November 1996 onwards, this final report will also be available on the COMMITT-site.

The website facilitated the communication among the international committee. The number of people who visited the site was not registered. Interested people could send their comments on the committee's 'starting notes' and the 'intermediate report'. They could also indicate that they would like to be informed about the committee's work. Almost 100 people from all over the world indicated via the web-site to be interested in the committee's work.

\subsection{Structure of this report}

In this report, the frame of reference of the committee is explained in three different chapters, in order to make the views and assumptions that underlay the committee's work explicit. Chapter 2 describes an analysis of the transformation of our society and the consequences for learning in the future. The third chapter discusses the key-elements in the teaching and learning process. A conceptual model is presented which serves as a frame of reference for COMMITT. The role of ICT in the teaching and learning process is discussed as well. These three aspects (society at large, the teaching and learning process and the role ICT could play in this process) are combined in Chapter 4 in the scope and focus of the committee's work.

Those readers who are mainly interested in the proposed program of action could start reading from Chapter 5 onwards. This chapter describes the consequences of implementing ICT for the education system and teacher training institutes in terms of challenges, opportunities, and possible threats. Guidelines for a program of action, derived from the previous chapters, are elaborated in Chapter 6. The program balances between 'care' for the people that have to work within the existing system but at the same time have to change, and 'courage' to experiment 
and create innovative practices. A strategic effort, starting with a program for seven years, is proposed to stimulate developments into 'A Leap for the Future'. Finally, Chapter 7 includes concluding remarks with a special emphasis on issues and factors which are expected to influence the implementation of our 'Leap for the Future'. 


\section{Society at large: A frame of reference}

This frame of reference makes the assumptions and viewpoints that underlie the conclusions and recommendations of COMMITT explicit. Society is in a process of transformation (2.1). As will be argued in section 2.2, it is hard to describe the future with current terms and meanings, especially with regard to new concepts from a new paradigm. The role of information and communication technologies in education cannot be separated from the changes of education. These changes are non-linear and have their roots and sources in society. Looking closely at the relation of education and society from a systemic point of view, it seems that new practices will emerge as forerunners of tomorrow's education: the demands from a new society can no longer be met by the current education system, as argued in section 2.3.

\subsection{Transformation of society}

'It is hard to predict, especially regarding the future', a distinguished politician once stated. If ever this was true, it is true today. Education is close to drastic changes. 'Education of the near future will be unrecognisable to us', the Dutch Minister of Education said at the inauguration of the committee on Process Management for teacher training (abbreviated in Dutch: PML, see section 1.1). The basic concepts of our education system are being replaced, as the challenges towards education cannot be solved anymore within the existing educational framework. The paradigm shifts.

Computers, especially when they are linked in networks, have the potential to change everyday classroom practice dramatically. The impact of the use of information and communication technology (ICT) in education will not be limited to the actors involved in the learning process (teachers and students), but will also change the institutional infrastructure, relations and patterns of behaviour within the education system, and even the content of education. For a good understanding of these educational changes it is necessary to look at the transformation our society (in the industrialised countries) is undergoing. In fact, education is reacting to the emergence of the information society. Traditionally, schools provided the settings where individuals were being prepared for the industrial society. In this society the focus was on 'making things', on industrial production. Today's education system faces the challenge to prepare individuals for the information society in which one of the most important aims is to handle information. Such a shift in focus can be seen as a new stage of our society, characterised by a new predominant paradigm. A simple overview of successive stages of development of our society is depicted in Figure 1.

The stages are not stable: in each stage changes and developments are taking place on a continuous basis. However, the changes tend to stay within the boundaries of the dominant paradigm and the reigning technology. Problems faced are basically variations of common practice, but the order of things is kept in place. After a period of time, successive variations are becoming less effective and tension grows until the next stage is apparent and a transition takes place. The conversion to a next stage is influenced by the availability of a catalyst of some kind (money, new energy sources, technological developments such as computers, networks, etc.). 


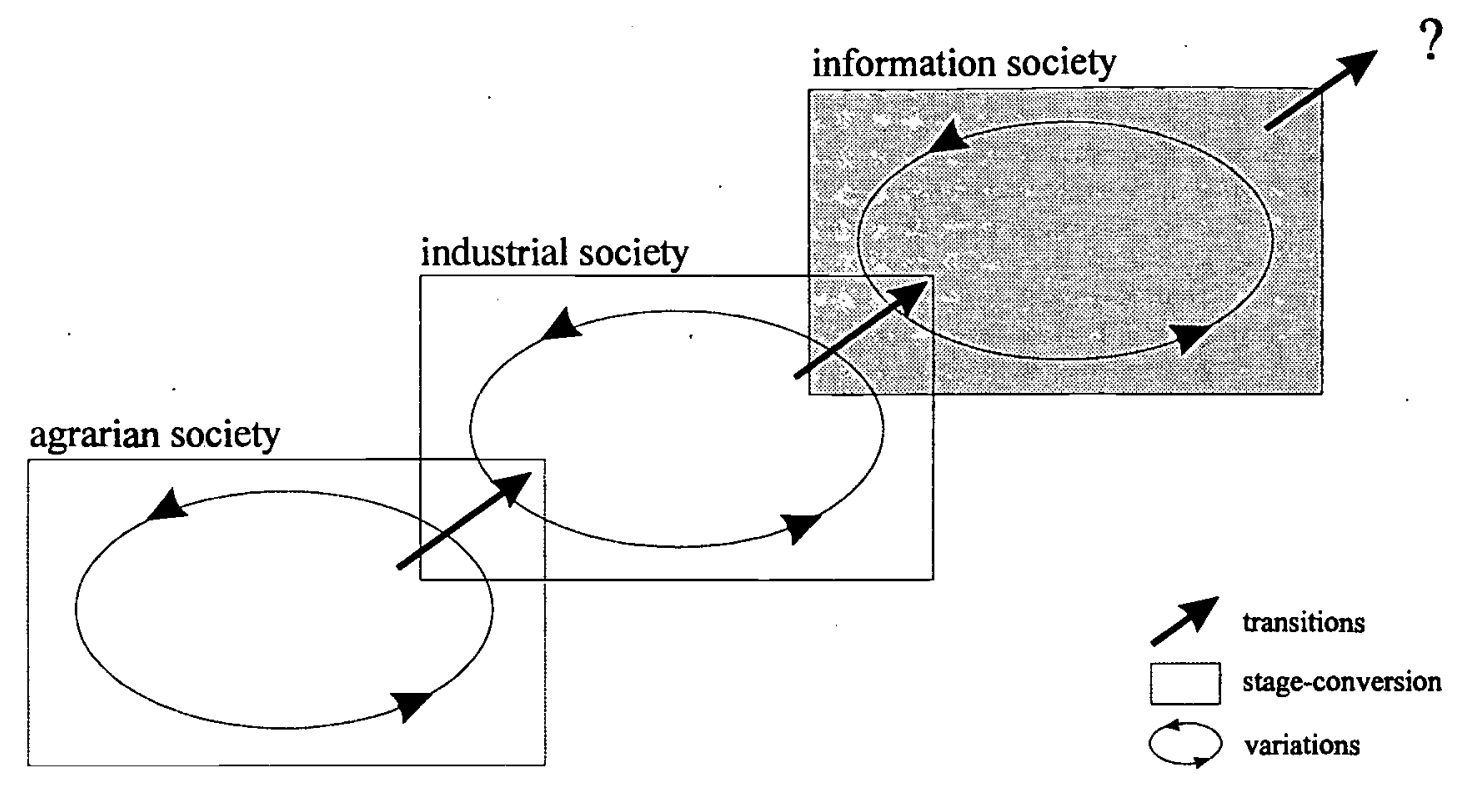

Figure 1

Successive stages in society

(Based on Van Dongen, 1996, unpublished)

In general terms, the mission of the education system is to provide balanced, personal, social, and vocational education, facilitating personal growth and development, citizenship, and providing preparation for a profession. Quality of education can be defined as the amount to which education is capable of realising these goals (Ministry of Education, 1990). Beside the challenge of preparing individuals for the information era, the education system is also facing other challenges:

- A contribution is expected from education to the solution of social, cultural and economical problems of society.

Education can no longer stand aside from all the problems of society: isolation, ethnic integration, juvenile delinquency, non-labour, etc. There is massive evidence that the level of someone's education correlates directly to the opportunities someone has in society (OECD reports 1988 - 1994).

- People want education to be individualised and flexible, suited to their specific needs.

Growing individualisation in and diversification of society calls for specific approaches in education. Standardised methods and classroom approaches will no longer be sufficient for individual needs.

- Life-long learning and new demands for learning.

The 1994 report of the SCP (the Dutch national institute for social and cultural studies) states that the growing number of people that is participating in education is the main problem that has to be addressed by the educational community. The guarantee for open and equal access to education for everybody is becoming almost unaffordable under the current circumstances.

It can be concluded that the near future provides all kinds of challenges and opportunities for the education system in our society. Managing large amounts of information, developing learning strategies to facilitate effective learning, and assuring that all citizens are proficient in assessing, selecting, and dealing with information are of critical importance. It is assumed that 
a shift from teacher oriented arrangements of the learning process towards more student oriented arrangements will be necessary. ICT provides a means to instrument these revolutionary changes called for by the evolutionary transitions in society. ICT as a tool to support the learning process holds a promise to new solutions for the challenges that education is facing.

\subsection{Our language falls short}

Given a transition of society, a transformation even, how can we describe the outcomes of such a process? Our language falls short:

1. Our idiom falls short:

We cannot describe the future beyond this transformation, not in the words, meanings and terms of today's system. How can we communicate, discuss and evaluate a future world, while we lack the proper words? Is it not a serious risk that we will use familiar terms, like 'school of the future', not realising that what we mean by 'school' today might be something completely different from the 'learning places' of tomorrow?

2. Our institutional frame of reference falls short:

By looking at today's institutions, we cannot foresee the characteristics of the educational institutions of tomorrow's education system, nor the way they will be organised. Our institutional frame of reference is shaped by today's education, or more likely by decades of educational practice and by our experience, that of our colleagues and our tutors. Even if we see the necessity for improvement in education, we are bound to see it as improvement of existing institutions: the school of the future, the teacher of the future, the class of the future, the school board of the future, the math subject of the future. It is very hard to imagine a world truly different from what we are experiencing today!

Discussions about the future of education, the role of ICT and the future of teachers are likely to be influenced by this 'shortage of language': one never knows what is meant and what is meant might refer to something that will not even be there in the future. This leads to two interesting questions for COMMITT. First, should COMMITT include (the activities of) existing educational institutes, like we know them today, in the description of the future? And secondly, should the proposed plan of action (presented in Chapter 6) be aimed at the development of new educational institutions, replacing the existing ones, or at improving or even transforming the current existing teacher training institutes? In the next sections, applying a system analysis point of view, these questions will be dealt with in more detail.

\subsection{A systems view}

From the perspective of a system analysis approach, we could regard society as the relevant environment of education. Education is defined here as the set of all educational practices; society as the place where education finds its people and resources, and to which it delivers its results. Teacher training institutes are, among other institutions, subsystems of the education system. They provide education with adequately trained professionals.

Systems tend to equate. They tend to organise their internal processes and interact with their environment in such a way that they remain stable and viable. For that, they have to cope with 
the complexity of their surroundings and they do so by controlling variety. The variety of educational needs in society, for example, is balanced to the variety the schools can accommodate. No school can meet all of the individual learning characteristics of its students. For most of us, this is not much of a problem and we accept and adapt to the fact that the school offers a limited variety in learning possibilities. However, in order to stay in balance with (the learning needs of) society, schools have to maintain their level of variety above a. certain threshold level. When the learning offerings of a school drop below that level, too many student-learning needs cease to be met and the system gets out of balance. This imbalance could subsequently result in a decreasing number of registrants, a rise of drop-outs, less public and/or political support, increase of classroom troubles, etc. One cannot repeal the 'law of requisite variety' (Beer, 1985).

The same applies to the teacher training institutes, for which the education system is the relevant environment. Teacher training institutes cannot meet all the variety that exists in the educational practice of all schools and at the same time cannot stay too far from a certain level of variety. This results in a dynamic relation; education as a whole is reacting to changes in society and teacher training institutes have to change accordingly.

The teacher training subsystem is one of many subsystems that is related to another subsystem: the schools. Other subsystems that are also related to schools are for example institutions for curriculum development (like SLO in the Netherlands), test development (like CITO), support institutes (LPC), educational publishers, furniture providers, educational software developers, etc. Each of them has a specific function within the education system. Together they act as the safe-keepers of education. Whenever education has a need, expressed by the educators themselves, by management or by government administration, one of the safe-keepers will react with some sort of service and, in doing so, by implementing small but important changes. So, their (support) activities are not only defined by the existing education system, but in turn keep the education system within the margins of controllable variability. They are designed to act in this way. But this makes them more the custodians of the present situation, than the change-agents of education.

Besides these continuous adaptations, there is another kind of change emerging in education. We are referring to a change beyond the boundaries of controlled variety. This is triggered by a change of our society which moves into a new world or paradigm which we call the 'information society'. As long as education succeeds in answering the needs of society, it fulfils its function towards society and it remains stable and viable. But, when the demands that society puts to education can no longer be met by more variety, the education system itself needs to change. This need for change develops independently from the subsystem's balancing interventions, and is to a certain extent contradictory to them. The development to a new stage in the relationship between education and society implies a transformation of education as well as a new definition of education.

If we accept the view that society is transforming from an industrial stage to an information stage, there is no doubt that this information society will generate completely new definitions of education. These new definitions will come from the learning needs and possibilities in the information society, and they should not be regarded as a linear succession of today's education. The consequences for education of the transformation from the industrial society 
into the information society is depicted in Figure 2. ICT could play a role in every stage of transformation.

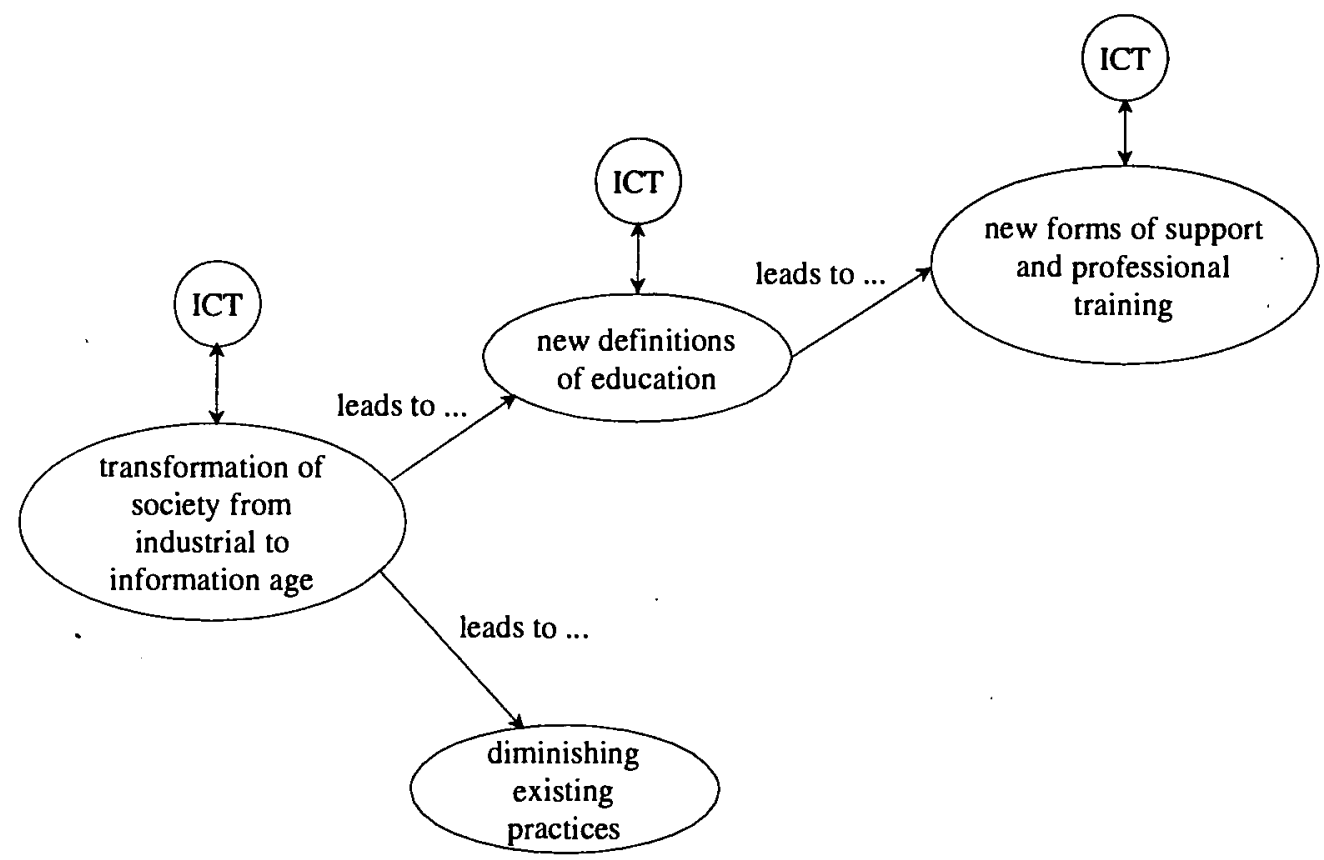

\section{Figure 2}

Transformation of society leads to new forms of support and professional training

In order to facilitate this transformation, it is required that the education system revises its relations with society, takes its needs seriously, and gives its demands the highest priority. These demands were already mentioned in the previous section as the challenges the education system is facing.

Some people might say that the transformation into the information society will not occur within the coming decade. However, there are already a number of signs of the need for the education system to change: the discussion on the 'study house' in upper secondary education, the increased emphasis in higher education on problem based learning, the 'knowledge debate' being held throughout society, the demands from business and industry to develop their capability of 'knowledge productivity'. These examples indicate that the transition is already taking place: it is a process which is irreversible. 


\section{The learning process and Imformation and Communication Technology}

For a good understanding of the potentials of ICT in education it is necessary to identify the key-elements of teaching and learning. This section gives a description of a conceptual model for the organisation of teaching and learning. At the heart of this model we find the learning process. The learning process can be seen as a common key characteristic of teaching and learning in the past, in the present, and in the future.

\subsection{The learning process}

Given the central place of the learning process and the different ways in which it can be arranged, it is important to identify the driving forces behind this process. We identify four forces, representing two dimensions. These dimensions and forces are depicted in Figure 3. The horizontal dimension represents the relation between the actors in the learning process: the teacher and learner or student. The vertical dimension represents the learning infrastructure, consisting of content, teaching and learning materials and infrastructure. The learning process takes place at the cross section of these two dimensions, as a result of a balance between the four forces: teacher, learner, content and materials. The contribution at the level of school organisation and management on the arrangement of the learning process (for example by providing a student monitoring system) is represented by the outer circle. The figure illustrates the view that a learning process is the result of both structural conditions derived from the learning infrastructure (at school and classroom level) and the personal characteristics of the actors involved, and their interaction.

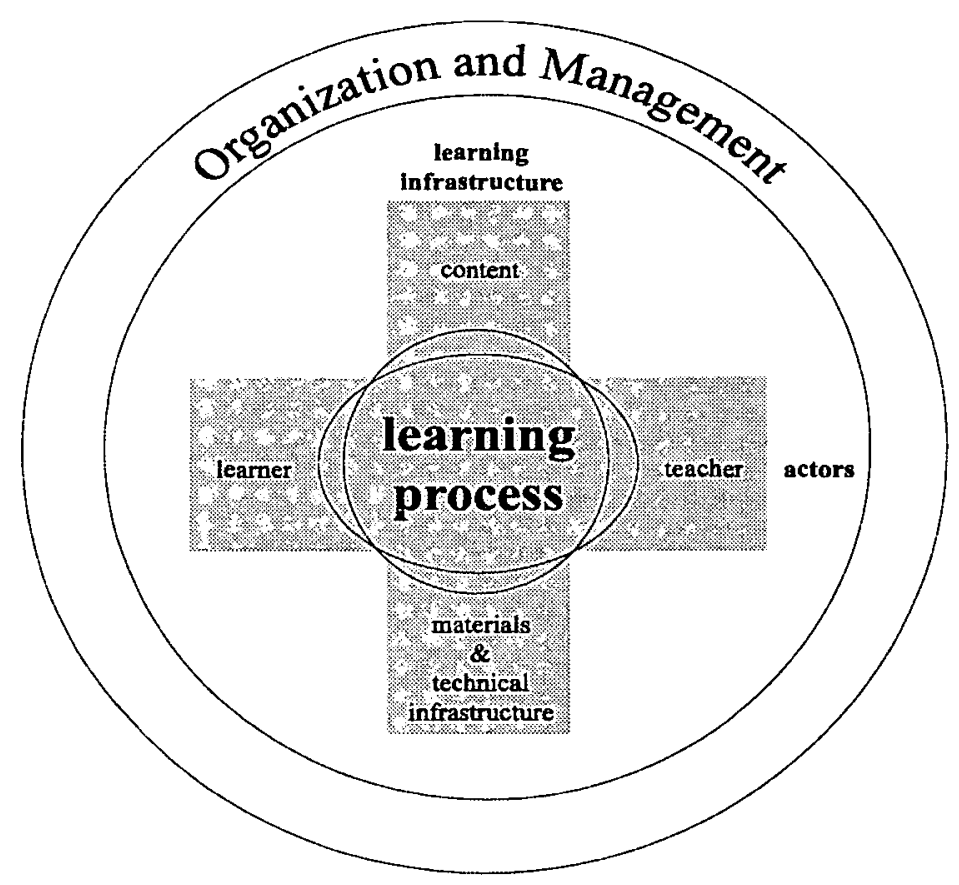

Figure 3

The learning process depicted as a result of activities and conditions for learning. 
Changing just one of the driving forces may lead to tensions, but not necessarily to substantial changes and improvement of the learning process. For example, providing schools with computers, software, and network facilities obviously changes the learning infrastructure in terms of availability of materials and technical infrastructure, but not necessarily the content of education or the roles of the actors in this process. Only in conjunction with changes in the roles of the teacher and the student, and with changes in the organisation of the content and corresponding curriculum materials is it possible to realise 'new' education and make use of the potentials such a new technical infrastructure holds for enhancing and renewing the learning process.

\subsection{Two approaches: teacher oriented and student oriented}

Adjusting education to societal needs of the future (the information society) means that schools have to enable learners to be continuously active in the sense of lifelong learning. Stimulating and supporting this process of continuous learning implies the elaboration of suitable learning processes in which the learner learns how to become more or less the architect of his/her own learning process. This means that learners have to be involved in the arrangement of their own learning process. However, learning always refers to a process in which the learner needs support in terms of well-adapted subject matter content, organisation of learning activities by a teacher, adequate materials and technical infrastructure. It is assumed that ICT has the potential to enhance such an approach of learning that not only prepares for but also suits the information society.

The role of the actors in the learning process (students and teachers), can be clarified by looking in more detail at the characteristics of the teaching and learning process in terms of concrete activities. Table 1 provides an overview of the activities that can be distinguished in relation to the learning processes (Simons \& Zuylen, 1995). The set of activities refers to three main categories of activities in the learning process: preparation, executing instruction, and regulation.

In a traditional arrangement of the learning process most of the activities listed in Table 1 are under control of the teacher. If a learning process is more student oriented it means, in operational terms of the activities listed in Table 1, that the student becomes more responsible for (part of the) activities which are completely under control of the teacher in the teacher oriented learning process. The terms teacher oriented and student oriented refer to the actor who is most active and responsible for the arrangement of the greater part of activities belonging to the learning process. There is no absolute distinction between both approaches because they indicate the opposite directions of a continuum. This means that both teacher oriented approaches and student oriented approaches have many different representations and that in an information society a new balance between the two is needed.

Chapter 2 described the view that society is in transformation toward the information and communication age. This future society will define its own institutions, such as education, anew. We can argue about the pace of change of society, be it evolutionary or revolutionary, but there is little room for debate that education and, even more, teacher training will need to change. 
Table 1

Activities in the learning process(Simons and Zuylen, 1995)

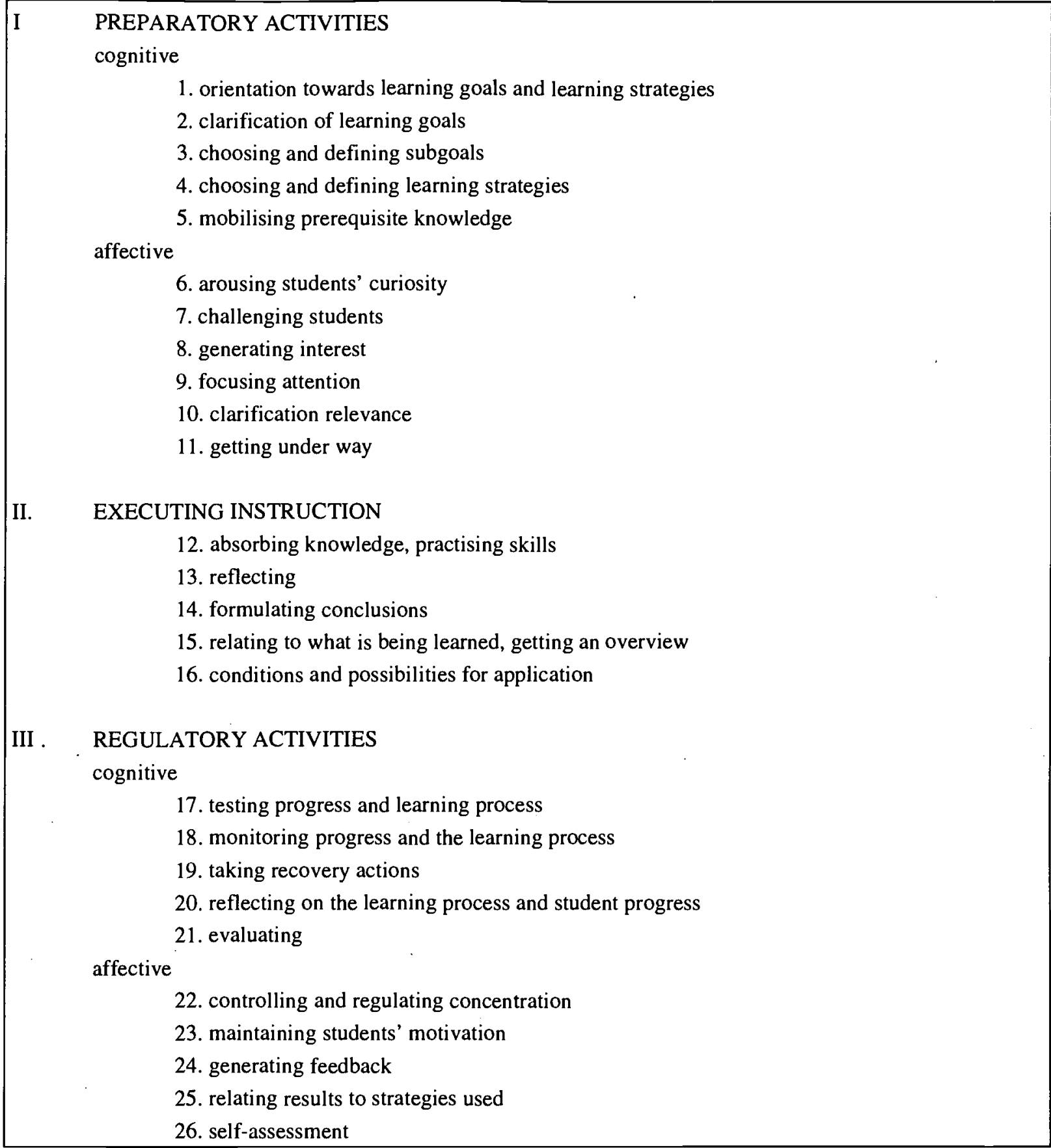

We can detect the future of education by carefully watching how the demands society puts to education are developing and how they are being met (or not). These demands are serious and to a certain extent also overwhelming:

- prepare students for the information age by giving them a solid education;

- contribute to the solution of problems such as isolation, ethnic integration, crime, nonlabour, etc.;

- provide individualised, tailor-made and flexible education;

- provide opportunities for life-long learning for everybody;

- solve financial, managerial and organisational problems efficiently; 
- prevent the occurrence of student-drop-outs, in-school violence, teachers-absence, skipping of scheduled courses, teaching by unqualified teachers, and so on.

\subsection{The role of ICT in the teaching and learning process}

It is assumed that a shift from teacher oriented arrangements of the learning process towards more student oriented arrangements can be facilitated by ICT. However, until now these potentials of ICT have hardly been implemented. Most of the current ICT-applications are used to facilitate the teacher oriented arrangements of the learning process. Applications of ICT are adapted to the existing teaching routines; the believes and attitudes of teachers towards their teaching practices did not change, and basically the teaching and learning process itself did not change (Pelgrum, Janssen Reinen \& Plomp, 1993). The use of ICT as a substitution of the current teaching and learning activities can be seen as the first of three phases through which the implementation of new technologies generally diffuses. The next section presents an overview of different ways ICT can be used in education, while the subsequent section deals with different phases in implementing ICT.

\section{Ways of use of ICT in education}

ICT appears in education in various ways. During the past years many ICT-applications have been developed for educational purposes. Most of these applications reinforce the existing teacher oriented instructional practice and some refer to new instructional methods. This section presents a classification of the various ways ICT has been used for educational purposes until now. Looking at ICT as part of the learning process, a distinction can be made in three different forms: ICT as object, as aspect or as medium (Ministry of Education, 1992). In addition ICT is often used as a tool for organisation and management in schools. In the latter case ICT is not integrated in the actual learning process but supports it at classroom level or even at school level (an example of an ICT application for organisation and management purposes is a student monitoring system).

\section{ICT as object, aspect and medium}

The use of ICT in education as object refers to learning about information technology and is mostly organised in a specific course such as 'computer education" or 'informatics'. As an object, ICT has been broadly implemented in the curricula of schools, especially in secondary education. Following the 'ICT-as-object-courses', students familiarise themselves with the most important ins and outs of information technology as a dominant phenomenon in society. Its educational aim is prevention of computer illiteracy. At present, education is quite good at this. But Walker (1994) warns that the easiest way to meet the challenge of technological revolution is to create and implement a new subject, so that the existing subjects do not have to change.

ICT as aspect refers to specific applications of ICT in education as used in industry, business and professional practice. Such a use in education is for the most part found in vocational education, for example in the training for computer aided design and manufacturing, and computer mediated accounting. Vocational training in these areas is unthinkable without ICT integrated in it. ICT as an aspect also appears outside the vocational territory, in subjects that are no longer teachable without the technology. For example, in general secondary education, carrying out experiments in science education, or accounting as part of economics. For that 
reason ICT has become an obligatory part of the general exams in science and economics in general secondary education in the Netherlands. The educational aim of ICT as aspect in education is job preparation. Today, ICT as object and as aspect are firmly embedded in our educational practice.

A third form of use is ICT as medium for teaching and learning. This refers to ICT as a tool for teaching and learning itself, the medium through which teachers can teach and learners can learn. ICT as medium appears in many different forms, such as in drill and practice exercises, in simulations, in tutorials, in individual learning systems (ILS), in educational networks, in hypermedia programs, in tests-generating systems, etc. A summary of the various forms of ICT applications as a medium is given in Appendix 5. We speak of ICT as medium whenever ICT is used to support the teaching and learning process and not specifically its content (which is the case when ICT is used as object of learning). Despite the variety on different kinds of ICT applications, current practices of actual use of ICT as medium are few, though there is a growing interest in applications of ICT.

The use of ICT as medium in the learning process in the educational field for which teachers need to be prepared, implies that ICT should be an aspect of the teacher profession. At this moment, ICT as aspect in teacher training is hardly developed, obviously because it is only used as replacement of existing practices. Apart from that, it is hardly used in the daily practice of teachers, other than as replacement of existing practices such as paper and pencil exercises. Consequently, the use of ICT as a medium to enhance the teacher training seldom takes place. 


\section{The scope of COMMITT}

The chapters above presented the committee's vision on society at large, the teaching and learning process and the possible role ICT could play in this process. This chapter summarises the scope of the committee on the interrelatedness of society and education and the implementation of ICT as a medium in education.

\subsection{The focus}

It is important to note that the scope of COMMITT primarily aims at the role of ICT as a medium in the learning process and, derived from this perspective, the use of ICT as an aspect of teacher training is a central focus. In other words, .COMMITT will look at the role of ICT to support the learning process in order to contribute to solutions for the challenges education is facing. It is obvious that the use of ICT as a medium in the learning process in the educational field for which teachers are trained, implies that ICT is an aspect of the teaching profession. This means that during their pre-service and in-service training teachers have to be prepared on using ICT to enhance the learning process. This is also emphasised in the report to UNESCO of the commission Delors: Learning: the treasure within (UNESCO, 1996). As the teacher is the key-person for arranging the learning process (now and in the future), and the professional preparation for this activity is the task of the teacher training institutes, it is self-evident that these institutes have to play a leading role in the implementation of ICT as part of the learning process in the educational field for which teachers are trained. In addition, the training of teachers can be enhanced by making use of ICT. This refers to the use of ICT as a medium in the teacher training institutes. It has often been found that new teachers tend to teach in the same way as they were taught, both when they were a child and when they were students in pre-service training.

COMMITT will look at ICT both as aspect and medium for teacher training. For the teacher training institutes, the two forms of ICT can be seen as the different sides of the same medal. Although ICT can also be used as an object of the teacher training curriculum, this perspective of ICT is not explicitly included in COMMITT's perspective. COMMITT primarily looks at the potentials of ICT to enhance the learning process and the corresponding challenges facing the teacher training institutes.

\subsection{Phases of use: an implementation perspective}

In general, new technologies can be implemented in three different forms which are also indicated as different phases of diffusion (Itzkan, 1994). These three phases of technological diffusion are shown in Figure 4. In the substitution phase, the technology replicates or automates the existing instructional practices. The technology is used for activities which people already execute in education, for example drill and practice exercises on the computer refer to the use of computers as electronic paper. In the transition phase, new instructional methods begin to evolve, like the use of e-mail in foreign language classes to communicate with peers who are native speakers. In this phase the technology is used for activities for which it was not necessarily brought in, and it is challenging old instructional practices. In the 
transformation phase, the technology provides completely new instructional situations and the old customs become obsolete. The instructional tasks for which the technology was originally acquired, may no longer be desired.

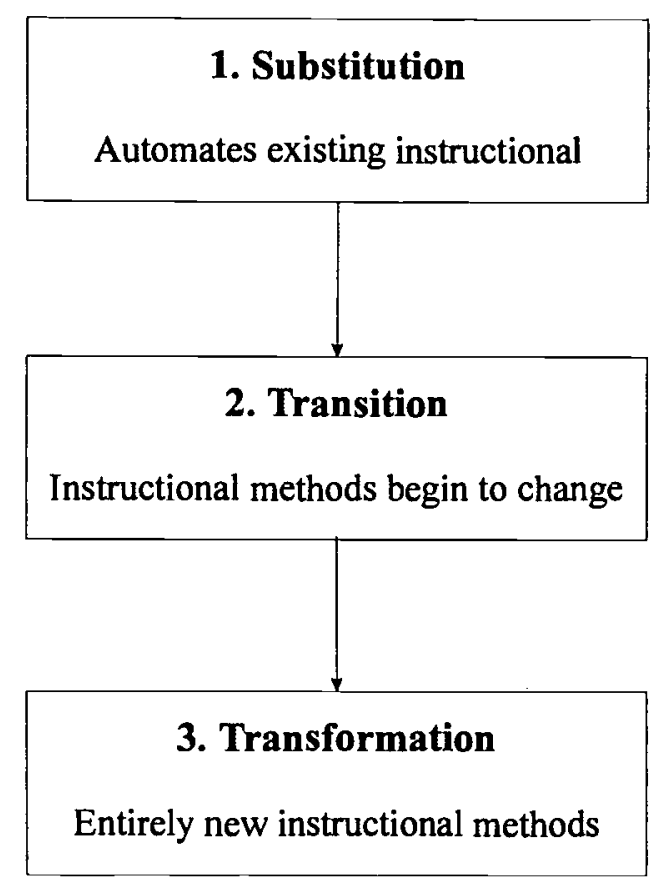

\title{
Figure 4
}

Phases of Technological Diffusion (Itzkan, 1994)

The underlying rationale of the phases of technological diffusion is that it is a mistake to suppose that new technologies will continue to fit existing or old practices. The following example is given by Itzkan (1994, p.62) to illustrate this process of technical diffusion:

\begin{abstract}
'When computers were first introduced in schools, they acted essentially as electronic paper, replicating drill and practice that was already familiar. Eventually new educational practices emerged, bringing with them instructional learning systems: HyperCard exploratory programs. Tomorrow's computers, however, may take us quite farther. Implementation of artificial intelligence and methodology taken from cognitive science (such as semantic networks) will allow computers to work on behalf of their user. They will recognise their speech, know what they are interested in, and facilitate exploratory learning through a world of contextual rich resources. Instructional methodologies will have to support variable time frames and individualised learning. Colourful descriptors of such instructional tools are 'cognitive agents' and 'knowledge navigators'. Gone will be the day of standard curricular models and practice. The computer will have made obsolete the very methods it was first used to reinforce'.
\end{abstract}

When we continue to use ICT for substituting existing practices, ICT will not contribute to solutions for today's problems in education. We might be left with only artificial interventions that by nature provide no way out for the problems of continuous harsh budget cutting (solution: more money), multi-cultural students (solution: more teachers), a continuous 
changing economy (solution: more specialised subjects), and a threatening non-labour market (solution: more study).

\subsection{Examples illustrating the impact of ICT as a medium for education}

Educators have used computers and other information technologies as tools to increase student learning for over 20 years. The 1970s brought computer-assisted instruction (CAI) to schools. CAI was developed to help students acquire basic skills, practice them, and measure learning gains. With the development and increased availability of lower-cost personal computers, the use of technology in schools broadened in the early 1980s to encompass the use of generalpurpose tools such as word processors and spreadsheets. Technology that allowed classes to be taught by remote teachers via two-way audio and video, known as 'distance learning', also appeared in school systems.

As we approach the 21 st century, several new, more powerful technologies are just beginning to make their way into classrooms. For example, new personal computers support 'multimedia' educational software that employs both sound and video to teach students facts and concepts. Advances in telecommunications technologies have spurred access to the Internet, allowing students and teachers to communicate with people from around the world via electronic mail, or 'e-mail' as it is commonly known. New ways of obtaining and presenting information have given students powerful new ways of analysing and understanding the world around them. In fact, not only are new technologies more powerful, but they are also easier to use and more accessible.

Through the use of advanced computing and telecommunications technology, learning can also be qualitatively different. The process of learning in the classroom can become significantly richer as students have access to new and different types of information which they can manipulate on the computer through graphic displays or controlled experiments in ways never possible before, and they can use a variety of media to communicate their results and conclusions to their teacher, students in the next classroom, or students around the world. This may lead to the phase of transition Itzkan (1994) distinguishes. For example, using technology, students can collect and graph real-time weather, environmental and population data from their community, use those data to create colour maps and graphs, and then compare these maps to others created by students in other communities. Similarly, instead of reading about the human circulatory system and seeing textbook pictures depicting blood flow, students can use technology to see blood moving through veins and arteries, watch the process of oxygen entering the bloodstream, and experiment to understand the effects of increased pulse or cholesterol-filled arteries on blood flow.

Promising examples of ICT use, or 'emergent practices', are practices that are prospective, because they anticipate the future. From 'surfing the net', literature and discussions with educators (from literally all over the world), a non-comprehensive list of characteristics : of emergent practices could be developed. Emergent practices:

- make heavy, but selective use of information and communication technologies;

- question. existing practices, not in form but in concept; are likely to be based on different definitions of learning, roles en responsibilities, ethics and values; 
- can be found in places where people actually learn, in schools and classrooms, less in offsite and secluded educational laboratories; besides in homes, streets, on sportfields, in theatres, offices; and tend to incorporate the whole world as a learning space;

- tend to override existing boundaries between subjects when it comes to learning;

- are to be found in unsteady environments with problems that seem hard to solve and demands unlikely to be met;

- are being practised by outstanding teams, with excellent teamwork, enthusiastic professionals who are learners themselves, are focused on learning of their students and create high morale and great fun; tend to create a strong atmosphere;

- seem never to get finished, are likely to respond to the reactions of the students and teachers.

Below, two examples are presented in more detail to illustrate the vision of the committee that integrating ICT in the learning process for other purposes than substitution of current practices, leads to changes in the roles of teacher and learner and also often results in changes in curriculum contents. The first example is based on findings of research and the second presents results from a site visit. The role of ICT in the learning process is strongly related to the pedagogical vision and educational goals of the school. Integrating ICT in the learning process is not only a matter of the infusion of new materials but it influences all aspects of the learning process. Not taking the interrelatedness of the driving forces of the learning process (see Figure 3) into account can be seen as a major obstacle for improvement of the learning process in general and for benefiting from the potentials of ICT.

The interrelatedness of the driving forces of the learning process is illustrated by the results of a study on the effects of using Internet in education (Harasim, Hiltz, Teles \& Turoff, 1995). Teachers who had used Internet as part of the learning process noted the following changes:

- the role of the teacher changed to that of facilitator and mentor;

- students became active participants; discussions became more detailed and deeper;

- access to information resources expanded significantly;

- learners became more independent;

- access to teachers became equal and direct;

- interactions among teachers were increased significantly;

- education became learner centred; learning became self-paced;

- learning opportunities for all students became more equal; learner-learner group interactions were significantly increased;

- teaching and learning increased;

- the teacher-learner hierarchy broke down: teachers became learners, and learners became teachers.

The results listed above clearly show that implementing new instructional methods by making use of Internet for educational purposes has impact on the roles of actors (teacher and learner) as well as the learning infrastructure (curriculum content and technical materials). Many other research findings could be added to support the committee's view on the interrelatedness of factors influencing educational change (Brummelhuis, 1995; Collis, 1994; Fullan, 1991; Grunberg \& Summers, 1992; Janssen Reinen, 1996). 
Members of the advisory committee visited schools in which elements of future education had already been implemented: so-called emergent practices. One of the visited schools was the Northbrook Middle School in Houston, Texas. At Northbrook Middle School students use technology as a tool to increase their learning and productivity in all subjects. Since 1991 the school has a policy aiming at a technology-rich, learner-centred environment. It was a clear policy choice of the school to use ICT in order to improve the teaching and learning process. After five years, the school has seen improvement of test scores, attendance records, student attitudes and self esteem, and discipline. The school serves a sixth- through eighth-grade population of under 800 students drawn largely from families of Hispanic migrant workers. Technology is employed to help students develop critical thinking and problem solving skills, and it is also used to tailor instruction to individual student needs.

To implement a more student oriented approach facilitated by ICT, Northbrook has relied primarily on on-site staff development. Each of the school's 48 teachers received two weeks of technology-related staff development. On an ongoing basis, teachers participate in three to four days of paid training each year on average. Additional personnel supporting the technology program includes a full-time technology assistant and a part-time district technology co-ordinator. These two individuals conduct training and keep the technology running smoothly. The case of Northbrook Middle school also confirms the position that making use of the benefits of ICT for the learning process requires changes in both the learning infrastructure and the roles of teachers and learners. The use of ICT has to be in accordance with the vision or pedagogical concept of the school. 


\section{Future educating}

\subsection{In search for a new balance}

It has been argued in the preceding chapters that our society is changing from an industrial society towards an information society. There are already many signs that this process is actually taking place. If our education system is to meet the challenges of the information society, it means an increasing need for learning situations responding to flexibility (adaptability to different needs), accessibility (learning when and whenever suits best) and support (an adequate learning infrastructure to assist learners).

Earlier, the learning process has been defined as the combination of both actors in the process (teachers and learners) and the infrastructure (in terms of content, learning materials and technical infrastructure). If this learning process has to change according to the needs of the information society, it does not merely mean a change in terms of putting technology in the classrooms; it means finding a new balance between all driving forces behind the learning process. In a traditional, mostly teacher oriented educational setting the teacher is completely responsible for the arrangement of most of the learning activities. If the current education system wants to meet the challenges of the information society, it is inevitable that the role of the teacher has to change and the student has to become more actively involved in the learning process. It is assumed that ICT is an adequate medium to support the shift from teacher oriented towards more student oriented ways of learning. Although it is uncertain to what extent this shift will take place and how much time this will require, the direction of future change is clear: the learner will become more responsible for the arrangement of his or her own learning process. Characteristic for such a learning process is that it responds to flexibility, accessibility and support. It is assumed that ICT can facilitate a learning process that meets these characteristics.

It is the task of the teacher training institutes to anticipate these developments and to prepare (future) teachers for these new roles. In other words, teachers have to be prepared for a new balance between student oriented and teacher oriented arrangements of the learning process. Even though flexibility, accessibility and support become the key issues of the education of the future and the students become more active, the teacher will continue to play a key role in the learning process. Teachers need to be trained in designing and organising such innovative teaching and learning environments because they continue to be the key actors in the teaching and learning process.

\subsection{Challenges for the education system}

The major question for the future is not whether education can be delivered on-line or will be supported by multimedia, but what is the best mix of didactical approaches to achieve the (partly new) goals of education within the constraints of the available resources and characteristics of the students. This means that the challenge is not getting technology and computers into schools but integrating information and communication technology into the teaching and learning process in order to improve the learning outcomes. 
Potential advantages of using ICT for the teaching and learning process are, for example, that ICT can help students learn at their own pace, provide them with unlimited sources of information, offer access to other learners and mentors which can be motivating for students of all ages. Using ICT as a learning medium offers students the opportunity to learn to collect information, organise their thinking, give meaning to information, revise their work, collaborate on projects with others, and present knowledge to audiences. These skills are relevant for students who have to be prepared for the information society in which one of the most important tasks is to handle information. Each student can not only proceed at his/her own pace but can also take certain responsibilities for learning as an active participant. The relevance of these possibilities become more important with the ageing of students; with optimal utilisation in upper secondary and higher education. ICT allows the student to focus on real problems, make connections to different fields of interest and construct their own knowledge. In such an approach the teacher's role is one of an adviser and a facilitator, arranging the conditions for learning.

\subsection{Challenges for the teacher training institutes}

Many schools do not make the most of the benefits of technology. One of the problems is that the school buildings are designed for the teaching and learning process belonging to the industrial era. Another problem is that teaching and learning in a technology enriched learning environment asks for new roles of teachers, new roles of the learner and an update of curriculum contents. But even in schools in which classrooms have all the characteristics of modern communication centres for learning, the basic tool of instruction continues to be the blackboard and chalk. It is clear that teachers must have more time and opportunity to integrate ICT into the curriculum before schools can benefit from technology. Recent studies (OTA, 1995; Brummelhuis, 1996) show that a majority of teachers feel inadequately trained to use technology and are not aware of how ICT can improve learning or help them to improve their job.

It is assumed that a new understanding of how we learn will result into several shifts in teaching methodology:

- from whole-class to small-group instruction;

- from lecture and recitation to coaching;

- from working with better students to working with weaker students;

- from assessment based on test performance to assessment based on product, progress and effort;

- from competitiveness to co-operation;

- from all students learning the same things to different students learning different things;

- from the primacy of verbal thinking to the integration of visual and verbal thinking.

These expected shifts can be facilitated by technology. Studies in the field of the implementation of technology in education show that many teachers go through identifiable stages on their way to become experienced technology users. In the early stages they use computers to support traditional methods of teaching, such as drill-and-practice, text orientation, whole group lectures and seatwork. Later on, as teachers gain confidence, they use technology as part of more innovative instruction, including team teaching, interdisciplinary project based instruction, and individually paced instruction. Finally, they enter an inventive 
stage in which they experiment and change using, technology to support active, creative and collaborative learning. It is this process that ultimately results in the shifts in teaching methodology that were described above.

In order to prepare student teachers for future education, the current teacher training institutes should shift their focus from serving the current education (teacher oriented) to serving what emerges as the education of the future (student oriented). Teacher training institutes have to create both space and opportunities in their program for such a transformation. This causes a dilemma because teacher training institutes cannot refrain completely from providing the current education system with teachers that can function in the existing situation. According to COMMITT, the solution for this dilemma is to distinguish a transition period first, covering the timespan from our current situation to the situation in which education will get its new shape. This implies strengthening the development of something 'new', while 'old' still exists. During the transition process 'old' needs care and attention, but should not prevent 'new' from growing. 'Old' should be challenged to 'emerge into new', but at the same time, 'new' needs stimulation and incentives. Thus, the transition period can be summarised in terms of both 'care' and 'courage': care for the existing practices and courage to explore and start new arrangements of the learning process. These are the leading principles for the program of action presented in the next chapter. COMMITT thinks this is very important for teacher training, as 'new' practice cannot be invented in the teacher training institutes itself, and subsequently cannot be implemented by their newly trained teachers in primary and secondary schools. The development of new practice is a matter of participation of all relevant partners in the process (such as teacher training institutes, schools, policy makers, parents). This means that teacher training institutes will have to establish and maintain close relations with teachers and students of primary and secondary education. The mutual exchange of new approaches for learning has to become a natural 'attitude' within the education system.

\subsection{Problems and possible threats of ICT implementation}

Implementing ICT in education is not only related to positive potentials. There are also a number of potential problems or possible threats related to the integration of technology in the teaching and learning process. Such problems and threats could be a reason for refraining from the process of educational change and ICT-integration. However, as indicated in Chapter 2, refraining from the developments will ultimately result in even larger problems. Being aware of the potential problems and threats should make us more conscious in elaborating our plans and strategies so that we can avoid these to happen.

\section{Ethical issues}

The use of computer networks can change everyday classroom practice in a drastic way. Interaction through networks connects students and teachers with the outside world. Until now, the teacher was the most important gatekeeper in school who controlled the degree to which the outside world could enter daily classroom life. In 'traditional' educational settings teacher control for this is only limited when it comes to student use of the library. Access to a computer, a modem and phone lines frees students from the physical limits and time constraints of a library and a school environment. Networking allows students to send electronic mail, participate in computer conferencing, and access information from remote sources. In that sense, the outside world may get a larger influence on the teaching and 
learning process. However, the prospect of students having open access to unrestricted materials (for example, violence and pornography) is a matter of great concern to many parents, educators, and community members. Many believe that children should be protected from being exposed to or having the opportunity of finding inappropriate information. It is clear that the Internet has not been designed with children in mind and therefore many potentially difficult issues still need to be discussed.

\section{Social aspects}

Integration of ICT in the learning process, and especially of Internet, will influence patterns of communication and interaction between students in a classroom, and therefore the learning 'culture'. A possible threat is that the interaction between students, needed for the development of social and communication skills, be replaced too much by student-machine interaction. Teachers and teacher students need to learn to recognise, analyse and assess the new learning environments on this potential threat and to learn that the use of ICT is sufficiently embedded in 'social learning'.

\section{Accurate and up-to-date information}

Internet is a huge decentralised network with information changing literally from minute to minute. The use of Internet for both professional development and instructional purposes requires constant accommodation to rapid change and tolerance for ambiguity. Going on-line in the classroom implies that the teacher is no longer the authority having all the relevant knowledge available; the teacher becomes a co-learner. This adds to the difficulty of teaching teachers the skill of using Internet. Different conditions of access to the net and different purposes for using it greatly affect the choice of an appropriate training model for teachers to get acquainted with this network. The quantity of information on world wide networks like Internet is staggering and finding the necessary information in a quick and efficient way is becoming more and more difficult. It seems necessary that effective filters become available to help teachers and students to find accurate and up-to-date information.

\section{Effectiveness, accessibility and equity}

Many schools (and families) do not have the means to judge the effectiveness of software programs and resources in increasing student achievement before purchase. Besides, the use of educational software by students at home is heavily skewed to higher income families. If students at schools do not have the opportunities to benefit from ICT's motivating possibilities for the acquisition of knowledge, (basic) skills and attitudes, this can cause a new area of inequity. 


\section{A leap for the future}

The earlier chapters lead to the conclusion that the teacher training institutes face a serious challenge: either they succeed in getting hold of the developments that lead to the future, or the future will take place without their participation. There is little doubt that there will always be a thing called 'learning' and there will always be educators to whom learners will turn in order to get guidance and support. However, it is fairly certain that the educators of the future will be quite different from the teachers of today.

We argued that our education system will change drastically in order to meet the demands of the information and communication age. Teacher training institutes will have to reform accordingly. They will have to pull together all their resources for a giant leap, in order to prevent 'missing the boat' of substantial change. COMMITT proposes a government program for teacher training to support that leap for the future.

There is a great need for innovators, but the transition should not be exclusively assigned to any one of the actors involved. The transformation of education as we see it, is basically decentralised in its framework. The program COMMITT proposes is designed to create conditions and opportunities for teacher training institutes to better understand the developments, contribute to them and create the next generation of professional training of educators in a participative and prospective way. Teacher training institutes who competently prepare for future teaching can also play a role in the retraining of the existing teaching force.

This chapter starts with a short reflection on the role of the government. The program COMMITT proposes, is an intrusion upon what used to be the teachers' domain (6.1). Underlying the program is the vision that a careful balance is needed between care for the current existing system and courage to build a new one (6.2). The strategy and the design approach are presented (6.3), before the program of action is described. The main activities distinguished in this program are: training, connectivity, challenges, learning technology centres, emergent practice projects, an experimental teacher training institution, and monitoring, reflection and research (6.4). An administrative and managerial structure is proposed for the program, but it is not too detailed in order to leave room for adjustments (and negotiation) (6.5). A calculation for the finances that are involved with this program will be presented in the last section (6.6).

\subsection{Reflecting the role of the government}

Throughout the decades that our current education system exists, the Dutch government has been reluctant to interfere with affairs that take place within the classroom. That was the domain of the teacher, his union or the religious denomination his school belonged to, but the state did not interfere because of the law on freedom of education. In everything else, the national government had a substantial say. The policy documents of the department of education have always been notorious for their rules and regulations, but never regarded the educational process itself. This attitude is changing as a result of de-regulation on one side and policy programs stimulating innovation on the other. De-regulation did not diminish government involvement, but it seems to be shifting from controlling input variables to performance indicators, one of which is teacher performance. Innovative programs have a 
growing impact on the teaching conditions. Policy documents are showing an increase of formulations of how teachers are supposed to address new developments.

This is not the place to analyse and contemplate the causes and effects of government involvement, but we have to realise that the program presented here, might be regarded as another step towards increasing government control of the teacher's trade. But despite this risk, COMMITT feels that the government should be committed to the quality of future education and the training of professional educators and should therefore provide the framework for innovation and change. As stated before, the proposed change process is expected to lead to a new practice of education and teacher training only if all different participants are involved. Teacher training institutes are not expected to be able to carry this change process all by themselves, the government and other actors in the education system should also be involved in this process.

This line of thinking is also reflected in the way the proposed program, called 'A Leap for the Future', is designed and should be administered. It is 'double-anchored': the program needs committed teacher trainers and teachers for its execution, but in order to stay on track and on speed, the program needs committed administrators and continued political support as well. According to the committee's view, the government plays a critical role in ensuring teachers to receive adequate training on how to use technology for improving teaching and learning, and the ongoing support they need to make good use of technology in the classroom. The government can begin by setting standards for teachers' skills in using ICT. Teacher certification requirements stating that all teachers and teacher trainers should have a working knowledge of educational technology and the skills to use it in the classroom in order to enhance learning would be an important signal to teacher training institutes and prospective teachers. For teachers who are in the workforce already, the government can require and encourage ongoing training in the use of ICT for the enhancement of the learning process.

\subsection{Vision underlying the program of action}

The basic assumption underlying this program of action is the necessity of a changing teacher and student role in the learning process, which can be characterised as a shift from teacher oriented instruction to more student oriented learning. The teacher of the future will no longer be the disseminator of knowledge, but an organiser and manager of the learning process. From a learner's perspective, the future learning process is constructive and goal-oriented. ICT will be an important tool to facilitate the change of focus from the teacher to the student. This change also allows for making use of the main advantages of ICT for the learning process: supporting more flexible (just-in-time) learning for every student. Besides, it is assumed that every student has a basic right to be introduced into the information society and to benefit from ICT's motivating possibilities for the acquisition of knowledge, (basic) skills and attitudes (the issue of equality). Finally, it is assumed that ICT helps break down the school walls, enhancing the 'real life quality' of school learning, encouraging the involvement of the home environment, the community and surrounding culture and even other cultures in the learning process, and helping to decrease the isolated position of the school and the isolation of the classroom within the school. 


\subsection{Strategy and design: riding the waves between care and courage}

The plan of action is based on a set of statements which have been developed during a committee meeting held on May 14, 1996. These statements are included in Appendix 3. The statements have been discussed with Dutch parties concerned in the field of ICT in education during a one-day-conference on May 15, 1996. The results of these discussions are also incorporated in the subsequent program of action. The proposed program has been discussed with representatives from teacher training institutes on October 21 and 23, 1996. Their remarks and recommendations (see also Appendix 4)are also incorporated in this final report.

The program's design is based upon two main considerations. First, the program should benefit from the transformation of society and the developments that take place in this large system (see Figure 5), instead of trying to maintain the old situation. Second, the program should show a balance between the courage needed to build a completely new educational practice and the care for the existing system and its people. Both considerations are described below in more detail.

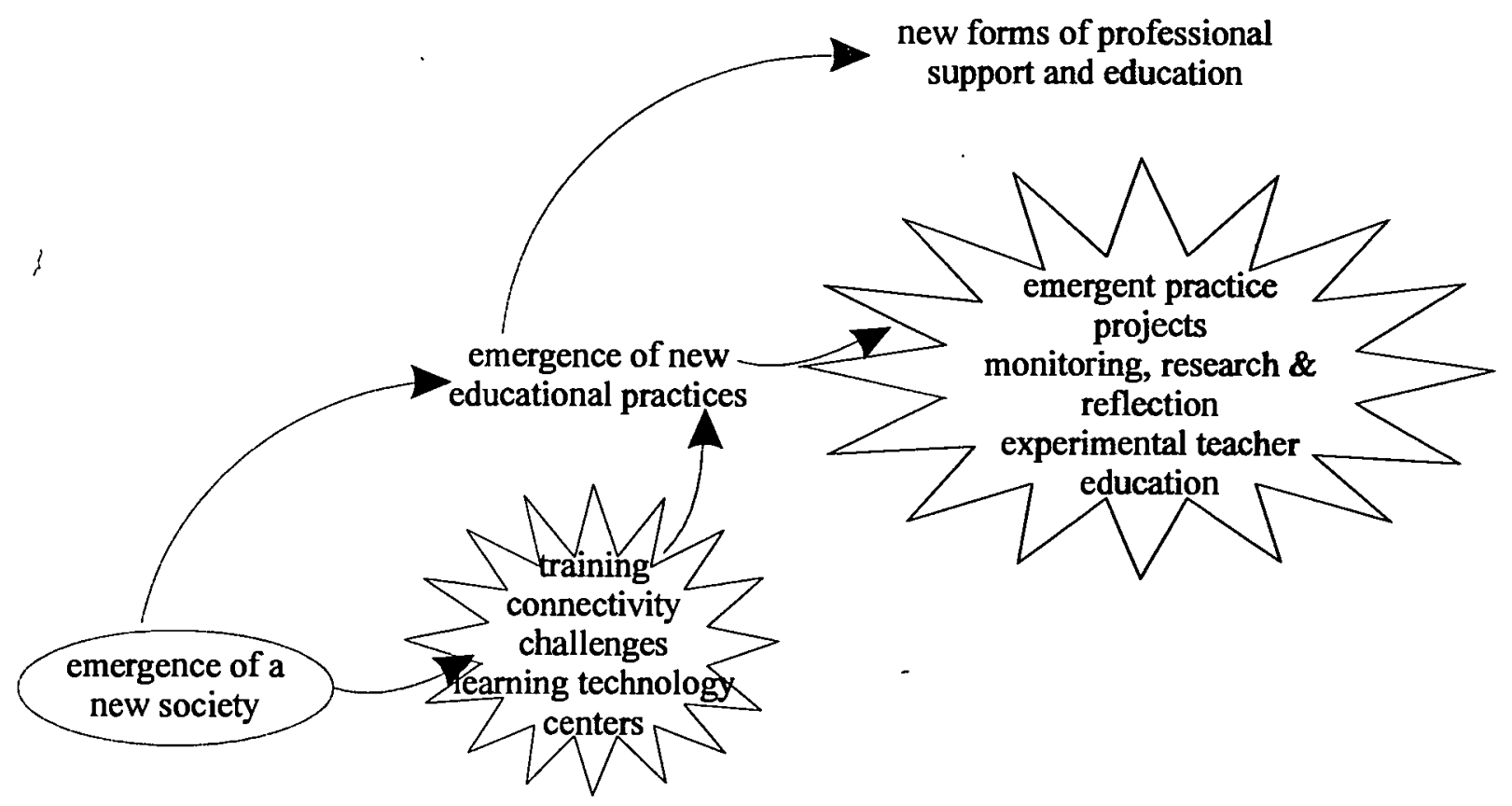

Figure 5

Riding the waves

The first consideration can be described as 'riding the waves'. We think that the best way to proceed would be to try to accelerate the developments that will lead to new educational practices. As we hardly understand their driving forces, it would be unwise to try to take control over them. However, the government can help the developments by generating, facilitating and empowering initiatives that are promising and meet the characteristics of emergent practices. Therefore, the government should support and accelerate the development of new and original forms of professional education and support. This is where we have to 
leap. As far as we can see now, emergent practices need a different type of support and education than most of the existing teacher training institutes are used to offer. Even if those institutes are willing to change, the change process will take a considerable amount of time. This change has to take place during the same period that the emergent practices are supposed to get support. Therefore we propose the creation of an experimental teacher training institute which can also act as an accelerator for the teacher training transformation.

The second consideration is that in the course of the program, both 'care' and 'courage' are concepts that have to be taken into account. The program should not exclusively be aimed at what has to be realised in future, but has to take care of the existing practice as well. It is the committee's view that the future of education will lead to the diminishing of existing practices and the emerging of new forms of education. Ultimately, 'new' will replace 'old'. However, we cannot and must not focus all attention entirely on the future and ignore the demands of the existing system. Classes must be kept running and school buildings must be maintained. Besides, some of what belongs to 'old' will be taken into account in new settings. People can be trained to acquire new skills, old buildings can house new ways of learning. All this requires care and attention out of respect for what has been achieved up till now and because we believe that it is possible for people and their organisations to change. Both concepts of care and courage and the relative attention for them in the course of time are depicted in Figure 6.

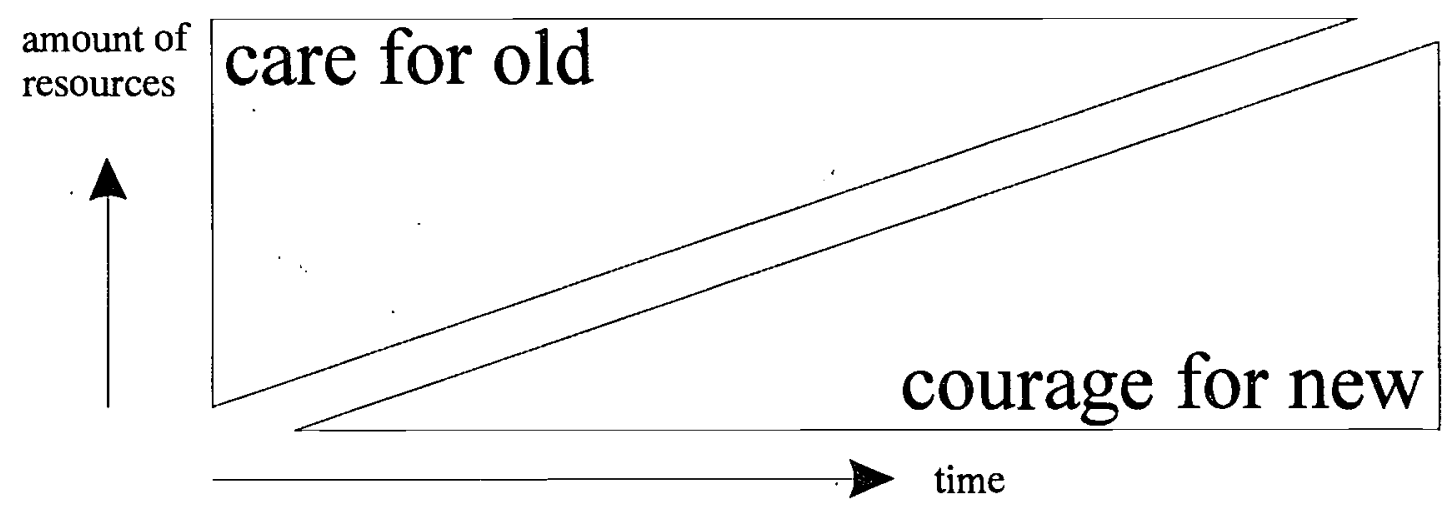

Figure 6

'New' replaces 'old'.

At the same time we have to realise that the transformation to new forms of education will start while 'old' still exists, and will not coincide with its passing away. Those new forms we called emergent practices, will initially look like harmless alternatives for existing practices, they will be equally competing for resources. It is hard to tell beforehand which practices will become dominant and which will prove to be less useful in the end. As more and more people are getting involved in these emergent practices, the consequences for the existing practice will gradually become clear and this will cause resistance. Without a program of action to help these emergent practices to flourish, the existing practice will have the tendency to continue, the more so when the existing interests benefit from continuation of the status quo. To initiate an emergent practice it takes creativity, to maintain its development and bring the experiences to useful results it takes endurance, but to keep up the intention of replacing existing practices it takes courage. 
As a consequence, 'care' for the current practice should not be mistaken for 'keeping things the way they are', nor for 'meeting the demands of existing interests'. In the committee's view, 'care' means preparing people and their organisations for transformation, building confidence and strength for 'the leap for the future'. From the committee's point of view, 'care' does not mean slowing down nor letting the responsibility for the direction and the speed of the process slip out of hand. 'Courage' on the other hand, should not be mistaken for an attitude that neglects the values of the existing education system.

In terms of government involvement, the concepts 'care' and 'courage' mean that the lower boundary of necessary skills in using ICT as an aspect of the teacher profession should be defined in the teacher certification and thus should form an integrated part of the core curriculum for teacher training. These lower boundary standards for ICT skills can be seen as governmental 'care' for the quality of the education system. Teacher training institutes and schools for primary and secondary education interested in exploring the potentials of ICT for the learning process can be seen as the 'risk takers' by working on emergent practices and thus belong to the concept of 'courage for the new'. The proposed experimental teacher training institute is a sign of courage as well. The role of the government for the courage part of the program would be to facilitate the activities of the risk takers.

\subsection{A program of action}

Based upon the considerations mentioned above, a program of action has been designed in a way roughly indicated in Table 2 . The committee emphasises that the program 'A Leap for the Future' is not a menu from which only some elements may be selected. It is a coherent and integral program and the set of proposed activities or components should be considered as a whole.

Table 2

The program of action summarised

\begin{tabular}{|c|c|c|c|}
\hline & \multicolumn{2}{|c|}{ creating and maintaining a transformable state: } \\
\hline & & care & courage \\
\hline \multirow{2}{*}{$\begin{array}{l}\text { accelerating } \\
\text { the } \\
\text { emergence of: }\end{array}$} & new practices & $\begin{array}{ll}- & \text { training }(6.4 .1) \\
- & \text { connectivity }(6.4 .2) \\
- & \text { challenges }(6.4 .3)\end{array}$ & $\begin{array}{l}\text { emergent practice } \\
\text { projects (6.4.5) } \\
\text { institute for } \\
\text { experimental teaching } \\
\text { education (6.4.6) } \\
\end{array}$ \\
\hline & $\begin{array}{l}\text { new forms of } \\
\text { professional } \\
\text { support and } \\
\text { education }\end{array}$ & $\begin{array}{l}\text { centres for learning } \\
\text { technology }(6.4 .4)\end{array}$ & $\begin{array}{l}\text { monitoring, reflection } \\
\text { \& research }(6.4 .7)\end{array}$ \\
\hline
\end{tabular}

Each of the proposed components of the program of action will be explained below in terms of concrete activities to be undertaken. 
6.4.1 Training for teachers, ICT staff, support staff and management of the teacher training institutes

Now that computers are available in all schools and in many households, a large number of teachers have become users of programs such as word-processing, database and spreadsheet. Beside for personal use, teacher trainers use these programs more and more to execute tasks associated with their profession. Teachers use the word-processor to develop lesson plans, they use databases to organise student records and spreadsheets to calculate grades. Thus, the teachers use the computer successfully as a productivity tool to improve their total professional performance. However, these skills do not necessarily lead to a change or an improvement of the learning process. Practical strategies for integrating computer use into instructional processes are difficult to discover or to create without experienced mentors and without training focused on this aspect. Training would support teacher trainers in their attempt to use ICT in improving the learning process. This part of the program aims at providing teacher trainers with a basic level of skills and knowledge about scenario's for the future learning process and the potentials of ICT for enhancing the learning process.

Special attention has to be paid to the training of the management of teacher training institutes. As this is a relatively small group of people (about 45 persons), training can be organised from the perspective of a so-called 'learning company': a group of people with common interests solving identical problems through training and exchanging experiences. This approach can be facilitated through the establishment of networks between the different institutes.

Summarising, the following activities can be distinguished within the training component of the program of action:

- develop scenario's for the future teaching and learning process in both pre-service and in-service teacher training;

- training in Information and Communication as integral parts of ICT skills and practices, including analysis and reflection on the ethical, social and cultural aspects of ICTpractices;

- networking and exchange of information between education institutions; these include teacher training institutes as well as other partners of the education system such as primary and secondary schools, support institutes, educational publishers, etc.

\subsubsection{Providing an infrastructure for educators: connectivity. for teachers (of the teacher training institutes and the schools) and learners (student teachers and students in schools), and easy access to resources}

ICT can enhance teaching and learning, and getting familiar with it is vitally important for preparing young people for the workplace of tomorrow. COMMITT recommends the establishment of an Educational Information Infrastructure to connect classrooms of primary and secondary schools and teacher training institutes. This infrastructure connects teachers (of training institutes and schools) and learners (student teachers and students in schools) to each other and provides a number of facilities, such as information exchange between teachers, providing resources in terms of concrete lesson materials or databases and supporting the professional dialogue about both subject matter issues and the teachers' profession in general. Concrete activities related to connectivity are:

- $\quad$ setting up local institutional networks (intranets);

- $\quad$ connecting intranets to Internet; 


\subsubsection{Challenging the teacher training institutes}

Crucial within this aspect of the program of action is challenging the teacher training institutes to become actively involved in the process of transforming the education process. This means that every teacher training institute will have the opportunity to be involved in the development of the 'education of the future'. These developments should take place through collaboration with schools for primary and secondary education (see section 6.4.5).

One of the issues raised before, to challenge education today, relates to the aspect of lifelong learning. This also holds for the teacher profession and therefore, the committee feels that training institutes should get involved in ongoing training for teachers, not only in terms of pre-service education, but also in terms of in-service education. Ongoing in-service training for the teacher profession is needed to communicate transformational trends (promotion activities, stimulating and facilitating a dialogue between teachers, showing interesting places via web-sites, national conferences where emergent practice projects will be presented, etc.). Concretely, the following activities are proposed:

- communicating transformational trends in general and the progress of the institutes in the transition process in particular;

- $\quad$ inviting teachers to participate in Emergent Practice Project activities (see below, 6.4.5);

- $\quad$ inviting managers and policy makers to participate in critical debates on policy issues and on the management of activities regarding the Emergent Practice Projects.

- Organising on-line and off-line physical and virtual discussions, and arranging study trips for Dutch educators within the Netherlands and abroad.

\subsubsection{Centres for learning technology}

It is assumed that every teacher training institute will establish its own centre for learning technology. These centres can play an important role in providing support to systematical integration of ICT for educational purposes within the institute as well as the schools related to the institutes. For this purpose the learning technology centres can participate in so-called emergent practice projects (see 6.4.5) by providing resources, consultation and workshops in the field of ICT. Centres for learning technology receive additional funding for every Emergent Practice Project in which they are involved.

Some centres can get a regional function, in terms of serving not only their own training institute and schools, but also providing support to other training institutes. This support could be related to specific subject matter areas or to the use of advanced technology needed for the execution of certain emergent practice projects. This means that not every centre has to develop a high level of expertise on every subject matter domain and on every aspect of technology use (like programming, or development of CD-ROMs).

The following activities are proposed for the regional centres:

- mobilising partnerships from current teacher training institutes and other institutions (support institutes, universities, business and industry, etc.) for support of the Emergent Practice Projects;

- developing methods and tools to support the Emerging Practice Projects. Support can be initiated both top-down and bottom-up.

- encouraging regional collaboration between institutional centres of learning technology in order to establish expertise centres. 


\subsubsection{Emergent Practice Projects}

Leading principle for the Emergent Practice Projects (EPP) is the collaboration between teacher training institutes on the one hand and elementary and secondary schools on the other hand. An EPP is a joint effort of teacher training institutes with these schools (and whenever appropriate also universities, research laboratories and private companies) to develop the learning process of the future and to gain experience in the effective use of ICT as integral part of it. Teacher training institutes should have the ambition to play a central role in these projects. Project proposals have to be reviewed against a set of criteria reflecting proper emergent practices. Accepted projects have to relate to completely new ways of the arrangement of the teaching and learning process, involving the use of ICT. Funding of hardware, software, development and related training is only permitted within the context of realising such a new arrangement of an educational practice in the teacher training institutes or in schools for primary and secondary education. Realised emergent practices should be disseminated to all teacher training institutes through the 'care' part of the program.

Summarising, this part of the program of action involves:

- $\quad$ stimulating and soliciting project proposals regarding the Emergent Practice Projects (EPP). An Emergent Practice project should create an example of the desired future arrangement of education, reflecting a student oriented teaching and learning process combined with the use of ICT enhancing the learning process;

- the possibility of submitting project proposals by teacher training institutes, in cooperation with schools for primary or secondary education and other institutions.

\subsubsection{Institute for experimental teacher training}

One of the aspects of the courage part of the program of action involves the establishment of an experimental teacher training institute. Such an institute can develop new approaches to teaching and learning without the burden of the traditional past, and personal and institutional limitations. As such, it can be considered as a 'greenfield-site'. It could take the risks of developing and experimenting with new approaches, from which the regular teacher training institutes can profit. Experiences that prove to be worthwhile can be incorporated within the regular institutes, negative experiments can be dropped without consequences. As such, the activities of the experimental institute could serve as an 'accelerator' for the regular institutes. The institute has a limited lifespan and should right from the start be aimed at the transfer of knowledge and experiences to the regular training institutes.

The regular teacher training institutes should be involved in the design and execution of activities of the experimental institute, in order to avoid this institute to become completely separated from the regular institutes. If possible, the establishment of the experimental institute should be considered in a European perspective.

Elements for the establishment of the experimental teacher training institute are:

- $\quad$ established and maintained by an independent administrative body;

- $\quad 50 \%$ of its budget financed by participating teacher training institutes, $50 \%$ as grants;

- . initial investments from government;

- advanced technological learning infrastructure;

- $\quad 75 \%$ of staff permanently (for the duration of the project), $25 \%$ temporarily recruited from participating institutes;

- $\quad$ increasing number of students; 
- a minimum of rules or regulations regarding curriculum and recruitment of students; but a guarantee of the qualifications of the students;

- co-operation with centres for learning technology regarding support of emergent practices.

\subsubsection{Monitoring, reflections, and research}

Almost every aspect of technology in education (hardware, connections, instructional content) is changing extremely rapidly. Universities and research centres have to be engaged in research on the use of technology in education to ensure an adequate knowledge base to guide school efforts. To ensure that research addresses critical issues, the research activities have to be integrated in and attuned to the program of action. Researchers have to collaborate with teacher training institutes and schools for primary and secondary education to focus on key issues.

An essential element in helping the teacher training institutes to meet their challenges will be to monitor the progress and provide regular updates on the developments that take place. At the start of the program baseline information is needed. Examples are the extent to which teachers are adequately trained to use technology in the classroom, the availability of an adequate infrastructure, the percentage of schools and classrooms connected to internal and external networks, and the use of effective software and on-line resources in the curriculum. Besides, detailed descriptions are needed on current educational practices which already reflect new approaches to teaching and learning. These promising examples can be found in the Netherlands and abroad and could serve as input for emergent practice projects.

Furthermore, research is needed on the factors that influence successful use of ICT in education. As indicated in Chapter 4, educational change is influenced by a complex set of interrelated factors. Although several research studies focused on this issue, the knowledge base is still too limited to provide policy makers and educators with clear guidelines as to which activities and support to focus on in order to make an innovation a success.

Activities belonging to this part of the program are:

- monitoring progress and results of the Emergent Practice Projects both on the level of individual projects as well as on a national level;

- organising moments of reflection for people involved in the Emergent Practice Projects, such as teachers, managers, researchers, policy makers, etc.;

- research activities on fundamental aspects of the teaching and learning process of the future and especially the influence of ICT on this process.

\subsection{Management and organisation}

'A Leap for the Future' is deliberately called a 'program', not a project. A course of action is only regarded a project when, among other requirements, the planned results, the activities and the necessary resources can be clearly defined and controlled. In a project, one knows what the desired results are and when the project ends. The program of action COMMITT proposes is at best a bundle of small projects with open-ended activities. The program needs regular reviewing in order to decide on concrete activities for a certain period ahead. Keeping the 
program within acceptable margins of time, money, quality and effects, is more a matter of political administration than of project management.

The administrative structure of the program is based upon 'balanced powers', which provides both room for leadership in the administration of the program as a whole as well as conditions for accurate control and management of the different lines of activities. Through the advisory and administrative bodies a balance can be found between 'care' and 'courage', but emphasis is placed upon the realisation of the predefined targets. Vested interests should be considered carefully. The program should act foremost as the explorer of future education. As indicated before, the minister of Education and the Council of Higher Education (HBO-Raad) have established a Process Management for teacher training (Dutch acronym: PML) to guide the developments regarding the organisation of and the curriculum in teacher training. Cooperation and mutual adjustment with the proposed program of COMMITT is obviously necessary. As the committee ends its work with the publication of this report, it will be up to the minister and the PML to determine in what way COMMITT's findings can and will be integrated in other developments.

The proposed design for the administration of the program is shown in Figure 7. A description of the program bodies and their duties follows below.

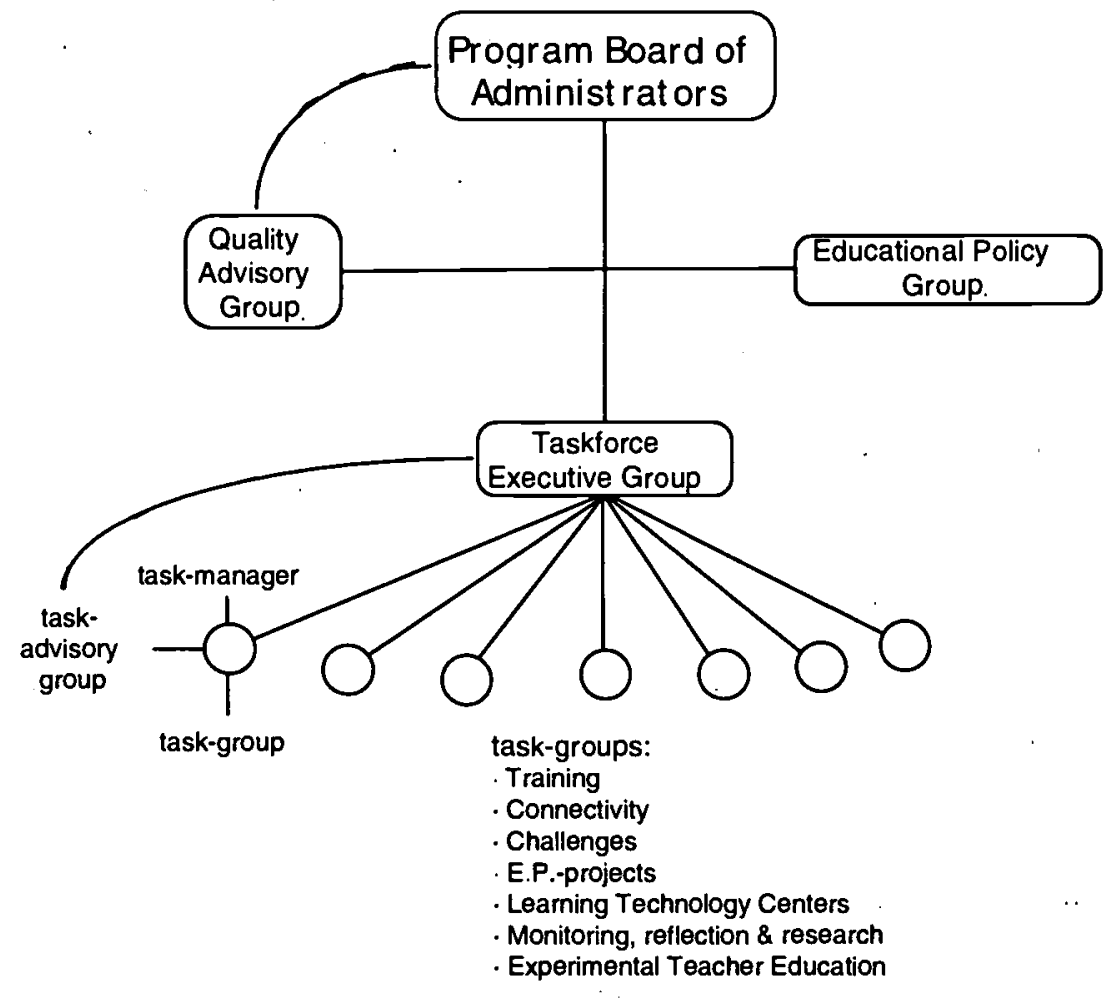

Figure 7

Administrative structure of the program 


\subsubsection{The task groups}

For each of the seven main activities depicted in the figure above, a task group will be established, managed by a task group manager. Task-group managers can be recruited from the teacher training institutes, in which case a detachment contract will be drawn up. The task group manager is appointed by and reports to the overall program director, who acts as the chair of the task force executive group. The task group managers are provided with means to realise the targets. This manager is obliged to accept critical assistance from a task advisory group. Task group activities will be carried out by the task group members on the basis of specific assignments or contracts. The group may be a virtual group, never meeting in 'real life' but always acting collaboratively under the guidance of the task group manager.

\subsubsection{The task force executive group}

The task group managers, together with the overall program director, form the task force executive group that directs the program. The overall program director chairs the executive group and is responsible for all program activities. This director reports to the chair of the Board of Administrators. The executive group meets once a month to monitor progress and to take initiatives for co-ordination and adjustment.

\subsubsection{The task advisory group}

For each of the tasks, a task advisory group will be established of approximately seven people. The duties of the advisory groups include:

- comment constructively but critically on visions, plans and activities of task groups;

- function as a consultative board for the task group manager.

The advisory groups are to act independently from existing interests, holding a strong commitment to the future. Nevertheless, they seek wisdom in balancing both concepts of care and courage in their comments and advice. The members of the advisory groups will be appointed by the Board of Administrators and will receive an attendance fee.

\subsubsection{The educational policy group}

In order to ensure the co-ordination of policy development regarding the program within the government and public bodies, a policy group will be established. The group will consist of representatives of the Ministry of Education, the Ministry of Economics and the National Council of Higher Education. Its members are to be appointed by the Minister of Education. The members of the policy group discuss the consequences of proposed and/or executed activities of the program for its respective organisations. Their target is to free the program from avoidable policy restrictions, to support the realisation of its goals by supportive policies, and to prepare the educational community for the relay of the temporary programorganisation. The policy group should refrain from co-managing the program as they are not in charge of the program.

\subsubsection{The quality advisory group}

The quality advisory group is the independent 'watchdog' of the program as a whole, committed to its goals and the only pressure group that is allowed to influence the execution of the program. Its four to six authoritative members are experts, recruited from universities, educational practice, government, and business. They will be appointed by the Minister of Education. Their duties include:

- obligatory comments on all program decision documents, as well as activity-plans and yearly budget proposals; 
- comment on monitoring reports of the executive group;

- advice in case of trouble, conflicts and barriers;

- function as ambassadors representing the program.

The members of the quality advisory group receive a fee for their efforts for the program.

\subsubsection{The program board of administrators}

The board of administrators represents the highest authority of the program. It holds the ultimate administrative responsibility for the program, acting on behalf of the Minister of Education. The board is chaired by the Director of Higher Education of the Ministry of Education and counts four members in total. Members come from science, education and business. At least one of its members is from abroad and at least one is aged under 20. The overall program director serves the board's secretary.

The board:

- fiats all plans and budgets;

- appoints the overall program director;

- represents the program formally;

- approves annual accounting reports.

\subsection{Budgets}

A program budget has been calculated, based on the parameters care, courage, communication and control. Each of these parameters will be discussed below, taking into account the activities of the program, summarised in Table 2 . The calculations are preliminary. Obviously definite budgets will be established when the program formally has been decided upon. In general, the proposed program duration is five years, preceded by a preparatory period in 1997 and followed by rounding off activities in 2003. In total the committee recommends to make budget reservations for seven years. The budget parameters discussed below are split up for each of these periods.

\subsubsection{Care}

Training

preparation:

setting up a financial and organisational system, based upon executing and controlling output financing of the required number of training activities; stimulating dedicated course development; recruiting providers and making an inventory of offerings; preparing logistics.

main program: . executing the sponsored training program, promoting participation by sponsoring each training activity with a fixed amount per participating teacher trainer; the training program is targeted at 7500 training activities for approximately 2500 teachers of teacher training institutes; 1000 managers, administrators and public officials; a technical support staff of 500; training providers are recruited from inside as well as outside education but it is assumed that teacher training institutes have a key-role in this process.

rounding off: $\quad$ seminars for teachers and managers, drawing conclusions for the future; writing evaluation and accounting reports; settling financial affairs. 
preparing individual and institutional offerings for Internet-connectivity; examining possibilities to support schools to establish intranets; setting up the financial system and organisation for handling applications. Decisions will have to be made regarding the efforts institutions already have made to establish and maintain existing networks; we propose a budgetary free space for these institutions, so that they, at their own discretion, can spend a fixed amount that depends upon the percentage of the school population connected and the budget reserved for this purpose.

main program: executing the connectivity sponsoring program, promoting individual connectivity through a donation to the school or teacher training institute for each individual teacher and learner Internet-account; there is a bonus for reaching increase-levels of $10 \%$ and more; the connectivity target is 31.000 teachers and students from teacher training institutes being connected in 2002.

rounding off: drawing up follow-up reports, evaluating and accounting reports, settling financial affairs.

\section{Challenges}

preparation:

main program:

defining, designing and preparing 'challenge-activities' according to the plan of action; publishing and promoting the plan. executing the plan for challenge-activities; activities may include participatory research and publications, road-shows, meetings and debates, posters and billboards; each challenge is financially standardised to a fixed amount.

rounding off: $\quad$ another ten challenges to break the habit.

\section{Learning Technology Centres (regional)}

preparation:

feasibility studies, technology assessment, establishing partnerships between teacher training institutes and primary and secondary schools; evoking plans for (regional) learning technology centres, based upon a support program plan with criteria, targets, etc.

main program: carrying out a competition for innovation grants; assessment of applications; allocating grants (four grants in 1997 and seven annual grants during 1998 - 2002) plus a fixed amount for each supported E.P.project-unit.

rounding off: $\quad$ this is not going to stop; preparing relay to the educational community; accounting and process reports.

\subsubsection{Courage}

\section{Emergent Practice Projects}

preparation: $\quad$ establishing criteria, setting up the system and organisation; drawing up the E.P.project-plan; call for proposals, promotion and meetings.

main program: executing the project-plan, targeted at 500 project-units (a unit being roughly a six months project activity in which an emergent practice at primary or secondary school level or within teacher training institutes is established with examinable results); handling applications, allocating 
fixed amounts for teacher training and project funding per unit; creating partnerships where necessary.

rounding off: there will be no concrete rounding off; the E.P.projects keep on going with 50 units in the last program year; the relay of the E.P.program is to be prepared.

\section{The institute for experimental teacher training}

preparation:

drawing up a comprehensive plan in co-operation with those teacher training institutes that participate; the plan should contain definitions of goals pursued, quantities and qualities of graduates, choices for technology, materials, infrastructure, housing, budgets, criteria for cooperation with schools, universities (within the country and abroad), number of staff members and amount and profiles of faculty; negotiating and settling funds with participants and government; establishing administrative board and hiring initial staff, recruiting students; the whole preparation might take as much as two years of hard work.

main program: $\quad$ educating educators while meeting the highest standards imaginable, but without policy or administrative restrictions and with the help of advanced information and communication technology; the institute should aim at a minimum of 25 students in the first year, at a minimum of 100 each following year; the institute has a fixed life-span of five years. Students could also follow only part of their education in this experimental institute. The rest of their courses they may have to take in one of the regular training institutes.

rounding off: finishing the financial support for the institute, relaying results to the participating teacher training institutes, publishing findings.

\section{Monitoring, research and reflection}

preparation:

drawing up a plan, establishing conditions for successful execution and partnerships; call for proposals.

main program: handling applications, allocating funds according to assessment results: annual costs cover fixed amounts for monitoring, for each E.P.project unit reflected, for fundamental research (based upon a temporary research institute, a professor and assistants).

rounding off: $\quad$ rounding off research activities, process and accounting reports, settling financial affairs.

\subsubsection{Communication}

\section{Communication}

preparation:

main program: executing a promotion campaign (based upon a communication plan) targeted at teachers and their management, both of initial education and teacher training institutes, setting the points of reference for the program.

establishing and maintaining an office for the program. The annual budget covers costs of editors, software design and programming for website, discussion lists, newspages and virtual meetings. 
rounding off: executing the relay campaign, supporting the relay of the program to the educational community.

\subsubsection{Control}

This fourth parameter is called 'control' for reasons of alliteration, but to be exact, it should be called Administration.

\section{Board \& bodies} preparation:

main program:

rounding off:

defining duties and responsibilities of the administrative and advisory bodies of the program; mobilising qualified people, instructing them; arranging support, defining attendance fee for the boards involved. the annual budget covers costs of meetings based upon attendance fee settlement of the National Economic Advisory Board; each board has its own seminar and studytour budget.

organise evaluation meetings and rounding off seminar for the task advisory groups, delivery and relay meeting for the board of administrators and the educational policy group.

\section{Control and accounting}

preparation:

purchasing and setting up physical and virtual working space systems and procedures, hiring staff, contracting third parties, etc.; approximately $25 \%$ of annual costs.

main program: sustaining a program office with bookkeeping and accountancy at contract base, full time secretarial and administrative support, task group managers (six) preferably detached from partner institutions and a full time program director at contract base; costs of personnel activities and care; costs of control should not exceed $10 \%$ of overall costs.

rounding off: drawing up evaluation and accountancy reports; terminating contracts; relay of the results; preparing evaluation meetings, rounding off seminar and delivery and relay meetings.

\section{Program facilities}

preparation:

main program:

setting up initial inventory, hard- and software, physical and virtual workspace.

rounding off: maintaining of the facilities. disposing and/or relaying of inventory and other facilities.

Summarising, COMMITT feels that it is important to develop an investment mentality for technology, based on the understanding that new technologies do not simply involve a onetime, up-front expenditure for equipment, but also ongoing, recurrent expenses. These recurrent expenses involve costs to upgrade hardware and software, maintain special furniture and cabling, replace materials and supplies, and continually upgrade the skills and competence of teachers and management of teacher training institutes.

In general it will be difficult to estimate the costs for integrating ICT in education because there are huge differences between schools and training institutes in terms of what they have 
(infrastructure), what they know (knowledge and skill in ICT use) and what they want (vision of the teachers and schools on the use of ICT for teaching and learning).

\subsubsection{Reservations}

On the basis of these parameters, we propose to make the following annual reservations (in millions DFL, Figure 8):

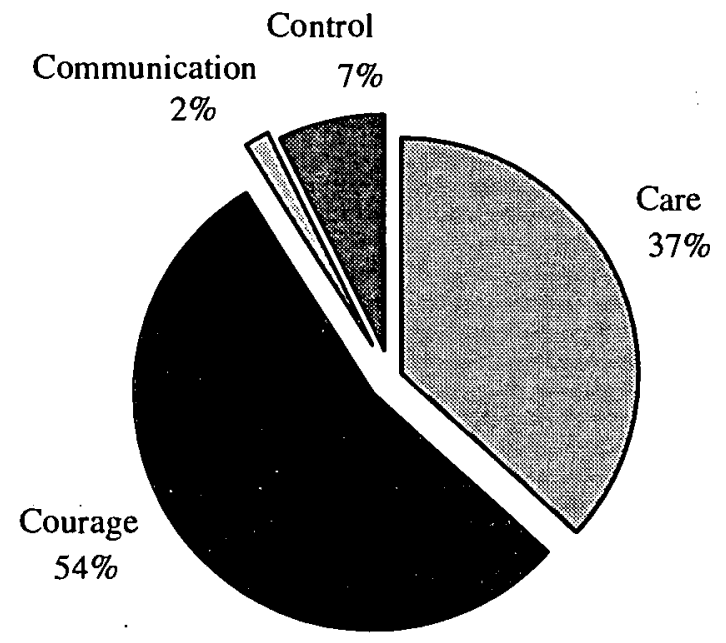

Figure 8. Distribution of costs over four parameters. 


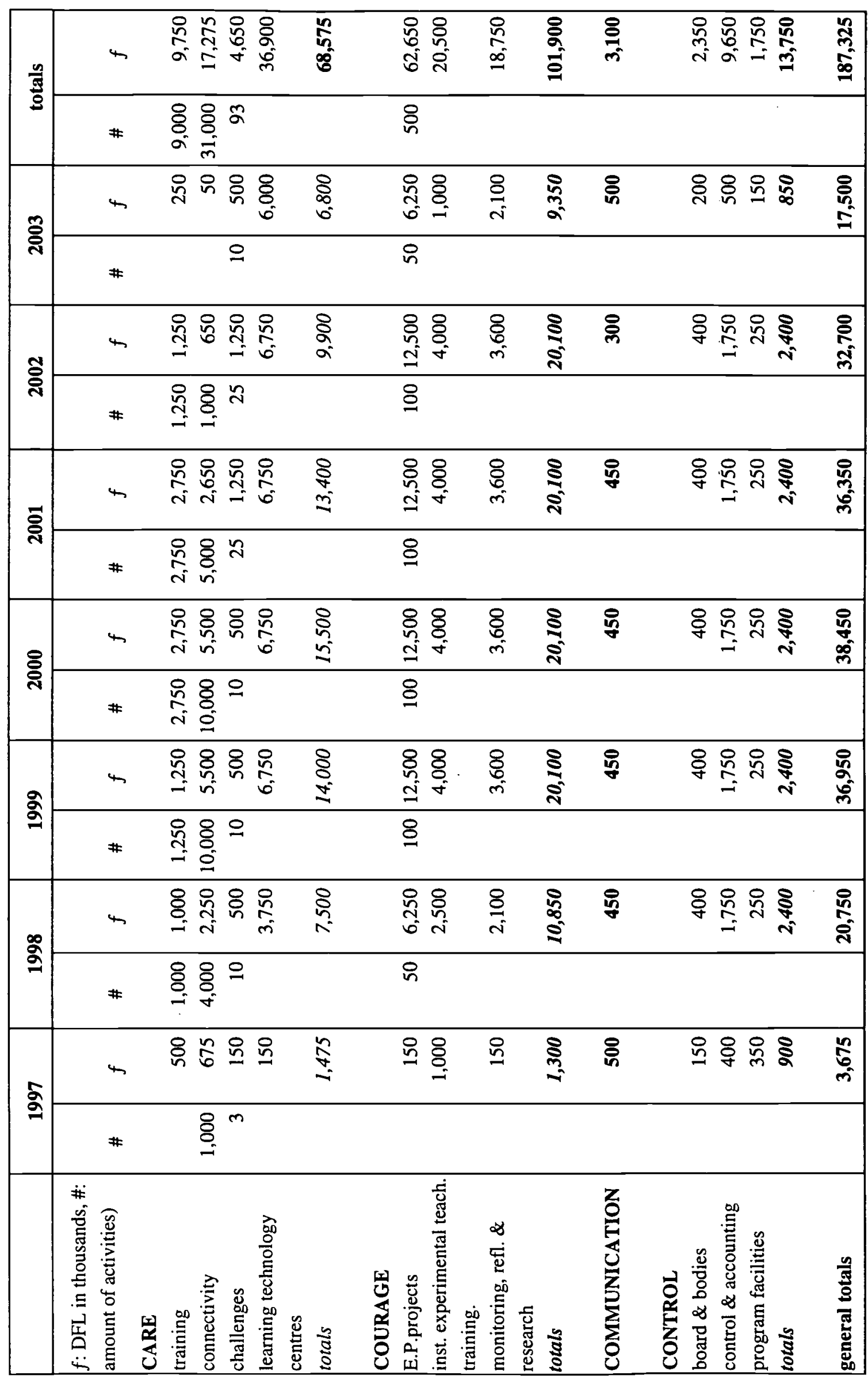




\section{Concluding remarks}

As the role of information and communication technologies becomes more and more dominant in society, there is a growing concern that education might lag behind. Evidently this is an area where teacher training has an important role to play. The COMMITT committee has been assigned to lay out a design for the role of information and communication technologies in future teacher training. In search for answers we studied educational literature and research publications. We 'surfed Internet' and acquired many samples of new practices initiated by a large and diverse group of educators. We had meetings with teachers, information technology co-ordinators of primary and secondary schools and teacher training institutes, with managers and administrators. In the end, we came up with what can be summarised in the following conclusions:

- ICT can be of help to transform education from teacher to student orientation, to become more constructive and goal-oriented and prepare students for the information age, break down barriers in schools and enhance 'real life quality' in learning.

- This transformation has its sources in society, in which an emerging information and communication society puts new demands to education; the existing education system will not be capable of meeting these demands without a major change.

- One should not try to design the future of education, and certainly not 'prescribe' a future 'ICT-school'. Instead, one should have a vision on education for the future, participate in emerging practices and shape the future while learning from these practices.

- The development of future teacher training ought to be based upon monitoring, reflection and research of emergent practices of successfully incorporating technology, for a number of years.

- A program of action is proposed to bring the future within reach, with a balance between care for the existing system and courage to initiate the future, and both aimed at accelerating new educational practices and developing new forms of professional support and education.

- Administration and management of this program requires commitment to future education and independence from (not negligence of) interests in the existing education system.

The committee would like to stress the importance of leadership in the management of teacher training institutes. Participation in this program implies implementing major changes in the current setting. The committee realises that this is far from easy and therefore the program pays special attention to the efforts faculty, management and administration have to put into the process of change. The terms 'care' and 'courage' bear a special meaning if one carries the responsibility for an educational institute. As indicated in section 6.4.1, training and support for the management of the institutes is considered to be crucial, aiming at developing leadership for the transformation.

The proposed program cannot be perceived as a menu from which only some elements can be selected. The program reflects an integral approach which asks for an appropriate management structure on both policy level and executing level for the duration of the program. The management at the executive level should be independent from institutional interests. A proposal for an administrative and managerial structure for the program as well as the calculations for the finances are included for a period of seven years. The program has to be attuned to other innovations in teacher training, managed by the 'process management for 
teacher training' (PML). For example, the new core curriculum for teacher training should reflect the recommendations of COMMITT.

The program has defined measurable targets for each of its activities, but the overall success of the program should be measured as well. As the final evaluation of the program is a political one, the set of indicators determining the ultimate success of the overall program should be developed in the preparatory period by the body that will hold the ultimate responsibility for the program.

Though much is still unclear or needs further and more detailed elaboration, this report does contain many choices and reflects certain visions with respect to society in general and education in particular. The Minister of Education, policy makers, the teachers and managers of teacher training institutes will have to make up their minds about the views and proposals presented in this report. After that, depending on the outcomes, the plans have to be brought into action. When that happens, this advisory Committee On MultiMedia In Teacher Training will consider its assignment successfully completed. 


\section{References and Sources}

This report of the committee is inspired by a lot of sources to which no explicit reference is made. Anyone interested in these sources can find an overview on the COMMITT web-site in the sections urliography and bibliography. In this report explicit reference is made to the following publications.

Beer, Th. de, (1985). Lokaal bestuur in Nederland: de pluriforme werkelijkheid binnen een wettelijk kader [Local administration in the Netherlands] . Alphen aan de Rijn (the Netherlands): Samson.

Brummelhuis, A.C.A., ten (1995). Models of educational change: the introduction of computers in Dutch secondary education. Enschede (the Netherlands): University of Twente.

Brummelhuis, A.C.A., ten (1996). Vertrekpunt voor verandering: de beginsituatie van Enschedese scholen voor voortgezet onderwijs bij de vernieuwing van de Tweede Fase [Starting point for change]. Enschede (the Netherlands): University of Twente.

Collis, B. A. (1994). Computers in education. In: T. Husén \& T.N. Postlethwaite (Eds.), International encyclopedia of education, 2nd edition (pp. 1007-1012). Oxford: Pergamon.

Fullan, M. G. (1991). The new meaning of educational change. London: Cassell.

Grunberg, J., \& Summers, M. (1992). Computer innovation in schools: a review of selected research literature. Journal of Information Technology for Teacher Education, $I$ (2), 255-276.

Harasim, L., Hiltz, S.R., Teles, L., \& Turoff, M. (1995). Learning networks: a field guide to teaching and learning online. Cambridge: MIT Press.

Itzkan, S.J. (1994). Assessing the future of telecomputing environments: implications for instruction and administration. The computing Teacher, 22 (4), 60-64.

Janssen Reinen, I.A.M. (1996). Teachers and computer use: the process of integrating IT in the curriculum. Enschede (the Netherlands): University of Twente.

Ministry of Education (1990). Richness of the incomplete, challenges of education. Report prepared for the OECD.

Ministry of Education (1992). ENTER: the future (OPSTAP-reeks nr. 33). Zoetermeer (the Netherlands): Ministry of Education.

Ministry of Education (1995). Vitale Lerarenopleidingen [Vital teacher training institutes]. Den Haag (the Netherlands): Sdu.

OTA: Office of Technology Assessment (1995). Education and Technology: Future Visions. Washington. 
Pelgrum, W.J., Janssen Reinen, I.A.M., \& Plomp, Tj. (1993). Schools; teachers, students and computers: a cross-national perspective. The Hague (the Netherlands): IEA.

Proces Management Lerarenopleidingen (1996). Scholen voor de toekomst: plan van aanpak Proces Management Lerarenopleidingen [Schools for the Future]. Den Haag: HBO-Raad / PML.

Simons, P.R.J., \& Zuylen, J.G.G. (1995). De didaktiek van leren leren [The didactics of learning to learn]. Studiehuis reeks nr. 4. Tilburg: MesoConsult.

UNESCO (1996). Learning: the treasure within, report to Unesco of the international commission on education for the 21st century. Paris (France): Unesco.

Walker, D. F. (1994). New information technology and the curriculum. In: T. Husén \& T.N. Postlethwaite (Eds.), International encyclopedia of education, 2nd edition (pp. 4081-4088). Oxford: Pergamon. 
Members of the Committee On MultiMedia In Teacher Training:

Mr. Hermann Astleitner

Mrs. Margaret Bell

Mr. Alf Gunnar Eritsland

Mr. Johan Heene

Mr. René Oosterling

Mrs. Renate Schulz-Zander

Mr. Per Unckel

Prof. dr. Tjeerd Plomp (chairman)

Dr. Alfons ten Brummelhuis (secretary)

Mr. Rob Rapmund (secretary)
Universität Salzburg,

Institut für Erziehungswissenschaften,

Akademiestrasse 26, 5020

Salzburg,

AUSTRIA

National Council for Educational Technology, Milburn Hill Road/Science Park,

Coventry, CV 4 7JJ,

UNITED KINGDOM

Hogskolen i Oslo,

Wergelands vn. 27, 0167

Oslo,

NORWAY

University of Gent,

Dept. of Teaching Sciences,

Henri Dunantlaan 2, 9000

Gent,

BELGIUM

Microsoft Hoofddorp,

Postbus 364,

2132 AJ HOOFDDORP

Universität Dortmund,

Institut für Schulentwicklungsforschung,

Campus Nord (CDI-Bau),

44221 Dortmund,

GERMANY

P.a. The Moderate Party,

Riksdagen, 10012

Stockholm,

SWEDEN

University of Twente,

Faculty of Education/CRC,

P.O. Box 217,

7500 AE ENSCHEDE,

THE NETHERLANDS

University of Twente,

Faculty of Education/OCTO,

P.O. Box 217, 7500 AE ENSCHEDE,

THE NETHERLANDS

Hoek, Geers, Rapmund \& Veldink,

Wolwevershaven 30,

3311 AW DORDRECHT,

THE NETHERLANDS 


\section{Appendix 2}

The Dutch education system

\section{Introduction}

Freedom of education, which is laid down in the Constitution, finds expression in virtually all facets of the Dutch education system. The threefold freedom - to found schools, to organize them and to determine the principles on which they are based - is the reason for the wide variety of schools in the Netherlands. People have the right, and the opportunity, to found schools based on their own religious or other convictions, or on their own educational principles. There are two main categories, namely public-authority and private schools. The latter may be subdivided into Roman Catholic, Protestant and private non-denominational schools. Private schools account for almost $70 \%$ of the total number of pupils.

Alongside the diversity of schools, there is a large measure of uniformity in many respects. Pupils can be certain that if they attended a particular type of school the qualifications they receive will always be recognized by other parts of the school system. Despite the great variety of schools, rules which apply to the system as a whole ensure similarity in the achievements of pupils moving into and out of the different parts of the system. These rules relate to the combination of subjects taken by pupils, the minimum time spent on each subject, examination syllabuses and national examinations. Full-time education is compulsory for all children up till the age of 16 . After full-time compulsory education it is compulsory to attend school at least part-time till the age of 18.

\section{The education system}

The Dutch education system comprises the following (see diagram 1):

1. primary education (for children aged between 4 and 12);

2. primary and secondary special education for children of all ages from 3 to 20 , who clearly have special educational needs;

3. secondary education for pupils aged roughly between 12 and around 18-20 years of age. This exists in the following forms:

- pre-vocational education (VBO), 12-16 years;

- senior secondary vocational education (MBO), 16/18 - 20 years;

- junior general secondary education (MAVO), 12-16 years;

- senior general secondary education (HAVO), 12-17 years;

- pre-university education (VWO), 12-18 years;

- adult general secondary education (VAVO).

4. higher education, for students aged about 18 and over. This may be subdivided into:

- higher professional education (HBO), 18-22 years;

- university education (WO), 18-22 years;

- open distance education (Open University), 18 years and over.

5. adult education and part-time vocational courses.

Primary schools cater for children from 4 to 12 years of age and provide 8 consecutive years of schooling. Primary education helps to lay the foundations for children to go on into secondary education. At the end of primary schooling, children go to the three-year period of basic education in secondary education. 
Primary and secondary special schools cater for children who, because for example of a mental, sensory or physical handicap, require more help with their development and education than ordinary primary and secondary schools can offer. At the end of primary special schooling, pupils generally go on into secondary special education or into one of the courses in individualized vocational education. Pupils may also be able to continue their education with secondary basic education.

Diagram 1

The Dutch education system

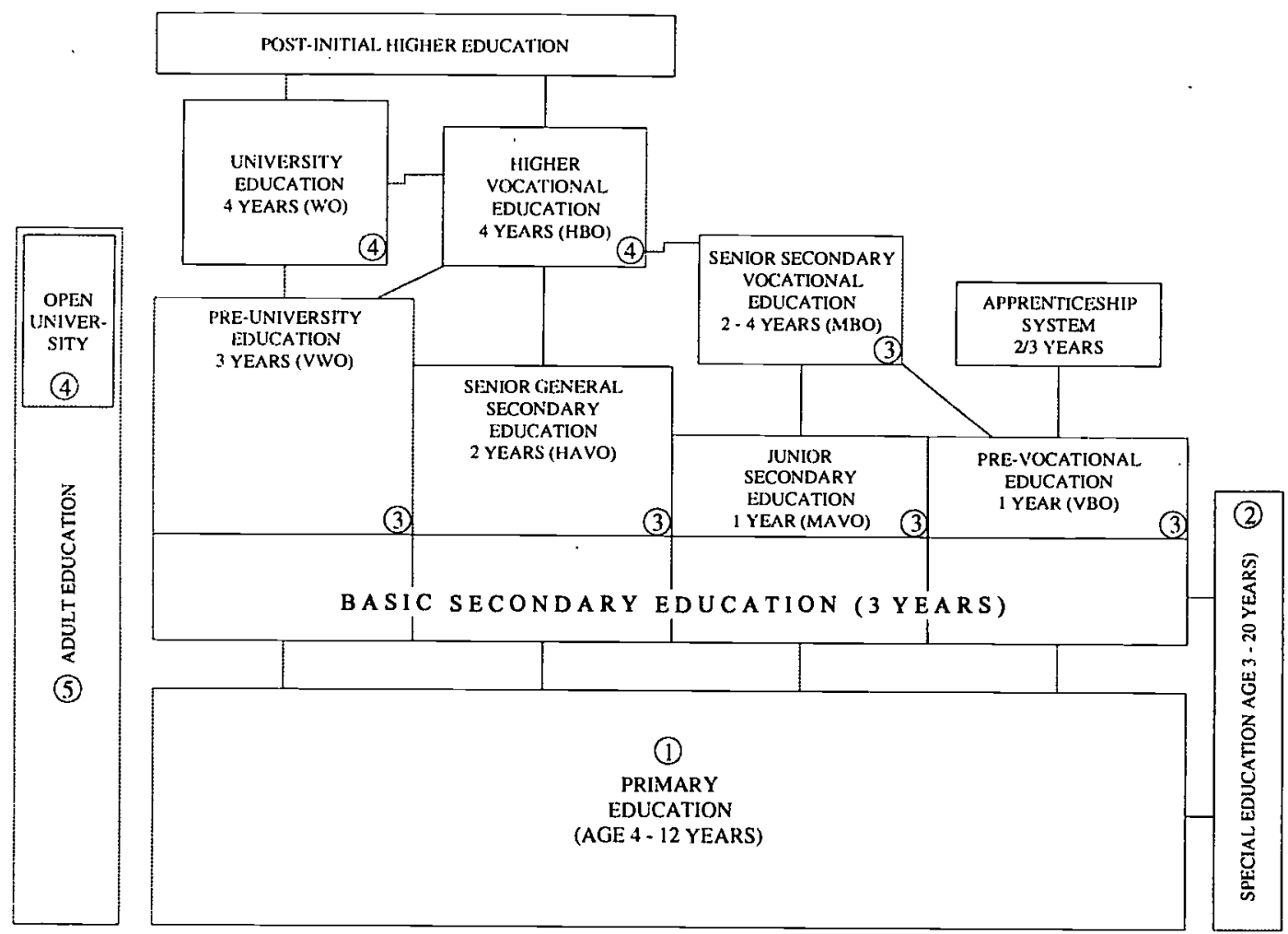

Secondary education follows on from primary education and caters for pupils from 12 to about 18 years of age. Since the starting of the 1993/1994 academic year, all courses begin with a period of basic education. In principle this lasts three years. It provides a broad general education and no strict distinction is drawn between general and technical subjects. Basic education is a curricular innovation within the existing schooltypes. After this three-year period, pupils follow one of the following forms:

VWO courses last an additional three years and provide a preparation for further study at university. In practice, students also go on from VWO into higher professional education.

HAVO courses last an additional two years after basic education and are designed to prepare pupils to enter higher professional education. In practice, pupils who have obtained HAVO qualifications also transfer into VWO or MBO.

MAVO lasts an additional year and is meant to prepare pupils for MBO. Many pupils with MAVO qualifications decide, however, to go on into HAVO or into apprenticeship schemes.

Pupils with $V B O$ qualifications (an additional year after basic education) can continue their education in senior secondary vocational education (MBO) and the apprenticeship system. This system is a vocational training scheme which involves spending one or two days a week at school and receiving practical training during the rest of the week. 
Those with an $M B O$ qualification (max. 4-year course) may be able to study further at $\mathrm{HBO}$ level.

Higher education, for students aged from around 18, includes three possible forms:

Higher professional education $(\mathrm{HBO})$ follows on from the level achieved at the end of VWO, HAVO and three-year MBO courses. HBO now has a two-tier system, like university education. The first phase, or undergraduate level, may last up to four years, the propaedeutic stage of which lasts no more than one year. Students may not remain registered as full-time HBO students for longer than six years. There are seven sectors in HBO: agriculture, teacher training, technical education. commercial education, social work and community education, health care and the arts. HBO establishments generally encompass several different sectors. University education (WO) is provided at the universities, of which The Netherlands has thirteen. The maximum length of $\mathrm{HBO}$ and WO courses is generally four years, although some statutory exceptions last as long as five or six years. Courses end with an examination. Like HBO, universities have a two-tier system. The first tier or stage comprises a 4-year undergraduate course (which must be completed in a maximum of 6 years) leading to an examination. Successful students are awarded the title of drs. mr (law graduates) or Ir. (engineering graduates); internationally they may use the title of Master. The second stage, to which a limited number of students is admitted, provides academic training at postgraduate level. Students on these courses, who are known as trainee research assistants or AIOs, are trained as researchers or design engineers. The courses vary in length from 1 to 4 years and are open to $\mathrm{HBO}$ as well as university graduates. University education follows on from the level achieved at the end of VWO. Some students transfer from HBO to WO.

The Open University $(O U)$ is designed to serve people aged 18 years and over who are unable or unwilling to taken an ordinary full-time course of education. Admission to the Open University is not conditional on previous educational qualifications.

Adult education means all those activities and facilities designed to provide education and training for adults. It encompasses the fields of adult basic education, non-formal education and development work with young people as well as courses provided at the accredited educational institutions.

\section{Teacher training}

Teacher training courses for the various types of schools are part of higher education (number 4 in diagram 1), either higher professional or university. There are the following courses:

a. Primary school teacher training courses, HBO courses whose graduates are fully qualified to teach at primary school. Full-time courses qualifying students last four years.

b. Teacher training in general subjects, HBO courses leading to a grade one or two qualification to teach at secondary school. Grade two teachers are only qualified to teach the first three years of VWO and HAVO, and all classes at MAVO, and VBO schools. Grade one teachers are qualified to teach every age group at all types of secondary school.

c. Teacher training in technical subjects, $\mathrm{HBO}$ courses leading to a grade two qualification to teach at secondary school;

d. Training for teachers of physical education, HBO courses leading to a grade one qualification to teach at secondary school;

e. University (postgraduate) teacher training leading to a grade one qualification to teach at secondary school. 
Primary school teacher training is, as stated above, a form of higher professional education. Graduates are fully qualified to teach all subjects at primary school, to all the age groups concerned. A HBO college which provides only primary school teacher training is called a 'pedagogische Academie Basisonderwijs' (PABO). A total of $40 \mathrm{HBO}$ colleges / PABO's provide teacher training (1993). Teaching practice is an important component of all teacher training courses. Students receive on-the-job training in the areas in which they intend eventually to work. This is a compulsory part of the training course and the component defines the period of teaching practice in the teaching and examination regulations. Around a quarter of the entire primary school teacher training course is devoted to periods of teaching practice, which begin as early as the first year of the course. Periods of teaching practice are spent principally in primary schools, special schools and school counseling services.

Secondary school teacher training courses can be attended either at HBO colleges or at universities. Universities provide only grade one courses, while HBO colleges provide courses at both levels.

\section{Higher professional education}

Grade two teachers of general subjects qualify to teach one subject. Full-time courses last four years. It is also possible to obtain a grade two qualification in one subject by attending a parttime course. After completing this, students may carry on studying part-time for a further three years to obtain a grade one qualification in the same subject.

Full-time teacher training courses in technical subjects and agricultural subjects last four years and part-time courses between four and six years. The teacher training course for physical education is a full-time course lasting four years. Graduates obtain a grade one qualification to teach that subject at every age group at all types of secondary school.

\section{University education}

University graduates can go on after their first degree to obtain a grade one qualification. This postgraduate university teacher training course leads to a qualification to teach a single HAVO/VWO examination subject and lasts one year full-time.

Also in these courses, teaching practice is an important component. Students receive on-thejob training in the areas of education in which they intend eventually to work. For courses to second grade teaching qualifications, there are no further specific rule for teaching practices/ The number of hours of practice is prescribed for the grade one training: this is 850 hours, 250 hours of which must be spent in a school. During at least 120 hours of this time, the student must actually be taking the class.

\section{Teacher training: miscellaneous}

For $M B O$ there is a different system: not only people with formal grade one or grade two teaching qualifications but also other graduates from HBO courses can be appointed, provided they also hold a certificate of competency.

A teacher training course for special education can be taken after completing the course for primary or secondary school teaching. This is a two-year part-time course to which only those with primary school teaching qualifications are admitted. Students can specialize in a particular field of work (e.g. teaching maladjusted children) and obtain a special education teaching qualification with the relevant endorsement. 
There are no specific teacher training courses for those wishing to teach in higher education. Lecturers at colleges of higher professional education (HBO) must hold a higher education qualification plus some proof of adequate teacher training. Staff on teacher training courses are. however, excepted from this broad requirement: they must have a grade one teaching qualification. For university lecturers, there are no specific training requirements. The structure of teacher training in the Netherlands is summarised in Diagram 2.

\section{Facts and figures}

Given the focus of this report on teacher training, only facts and figures will be given about the enrollment in the teacher training courses ${ }^{1}$.

Table 1

Number of full-time students in $\mathrm{HBO}$ teacher training

\begin{tabular}{|l|c|c|c|c|c|c|c|c|c|}
\hline & \multicolumn{3}{|c|}{1993} & \multicolumn{3}{c|}{$1994 / 95^{*}$} & \multicolumn{3}{c|}{$1995 / 96^{*}$} \\
\cline { 2 - 10 } & total & men & women & total & men & women & total & men & women \\
\hline Total & 36.841 & 11.305 & 25.536 & 39.474 & 12.415 & 27.059 & 38.900 & 12.100 & 26.800 \\
\hline $\begin{array}{l}\text { Physical } \\
\text { education }\end{array}$ & 2.372 & 1.392 & 980 & & & & & & \\
\hline $\begin{array}{l}\text { Sec. education } \\
\text { (NLO) }\end{array}$ & 16.743 & 7.080 & 9.663 & & & & & & \\
\hline PABO & 17.726 & 2.833 & 14.893 & 19.204 & & & & & \\
\hline
\end{tabular}

Note: * preliminary numbers

Table 2

Number of students in university teacher training courses

\begin{tabular}{|l|c|c|c|c|c|c|c|c|c|}
\hline & \multicolumn{3}{|c|}{1993} & \multicolumn{3}{c|}{1994} & \multicolumn{3}{c|}{1995} \\
\cline { 2 - 9 } & total & men & women & total & men & women & total & men & women \\
\hline $\begin{array}{l}\text { Number of } \\
\text { students }\end{array}$ & 545 & 246 & 299 & 700 & & & 800 & 400 & 400 \\
\hline
\end{tabular}

1 The sources from which these facts are drawn are:

- Zakboek Onderwijsstatistieken, 1994/95 (1995). Den Haag: SDU /CBS publicaties

- Website CBS, ... vb.cbs.nl/witch/etc/static 


\begin{tabular}{|c|c|c|c|c|}
\hline 40 Level & $\begin{array}{c}\text { Entrance } \\
\text { requirements } \\
\end{array}$ & $\begin{array}{l}\text { कo } \\
\text { Location } \\
\end{array}$ & Course structure & Qualifications/Titles \\
\hline \multicolumn{5}{|l|}{ Full time training } \\
\hline Primary education & & $\begin{array}{l}\mathrm{HBO}, 4 \text { years } \\
\mathrm{HBO}, \text { called } \\
\text { PABO }\end{array}$ & $\begin{array}{l}4 \text { years in general subjects, } \\
\text { professional studies and } \\
\text { teaching practice approx. } \\
\text { of the course }\end{array}$ & $\begin{array}{l}\text { Teaching certificate } \\
\text { Qualification } \\
\text { primary education }\end{array}$ \\
\hline $\begin{array}{l}\text { Lower secondary } \\
\text { (grade 2) }\end{array}$ & HAVO, VWO or & $\mathrm{HBO}, 4$ years & $\begin{array}{l}4 \text { years in one general } \\
\text { subject or in one technical } \\
\text { subject, pedagogical } \\
\text { subjects and teaching } \\
\text { practice. Didactics are } \\
\text { integrated in approx. }{ }^{*} \text { of } \\
\text { the course } \\
\text { University } 1 \text { vear in one }\end{array}$ & $\begin{array}{l}\text { Teaching certificate } \\
\text { Teachers with grade } \\
2 \text { qualification. They } \\
\text { can teach in the first } \\
3 \text { years of VWO and } \\
\text { HAVO and all } \\
\text { classes at MAVO, } \\
\text { VBO and MBO }\end{array}$ \\
\hline $\begin{array}{l}\text { Upper secondary } \\
\text { (grade 1) general } \\
\text { subjects }\end{array}$ & WO & wo & $\begin{array}{l}\text { VWO/HAVO examination } \\
\text { subject postgraduate } \\
\text { course of } 1700 \text { hours of } \\
\text { which } 850 \text { hours teaching } \\
\text { practice } \\
4 \text { years in physical }\end{array}$ & $\begin{array}{l}\text { Teaching certificate } \\
\text { Teachers with grade } \\
\text { I qualification, } \\
\text { allowed to teach } \\
\text { throughout } \\
\text { secondary education }\end{array}$ \\
\hline $\begin{array}{l}\text { Upper secondary } \\
\text { grade } 1 \text { physical } \\
\text { education }\end{array}$ & $\begin{array}{l}\text { HAVO, VWO, } \\
\text { MBO }\end{array}$ & $\begin{array}{l}\text { HBO, also } \\
\text { called ALO }\end{array}$ & education & $\begin{array}{l}\text { Teaching certificate } \\
\text { Teachers with grade } \\
1 \text { qualification in } \\
\text { physical education }\end{array}$ \\
\hline Part time training & & & 4-6 years & \\
\hline Primary education & $\begin{array}{l}\text { see: full time } \\
\text { training }\end{array}$ & $\mathrm{HBO}$ & 4 years in one subject or & $\begin{array}{l}\text { Teaching certificate } \\
\text { Qualification } \\
\text { primary education }\end{array}$ \\
\hline $\begin{array}{l}\text { Lower secondary } \\
\text { (grade 2) for a } \\
\text { general subject or a } \\
\text { technical subject }\end{array}$ & $\begin{array}{l}\text { HAVO, VWO, } \\
\text { MBO }\end{array}$ & $\mathrm{HBO}$ & $\begin{array}{l}\text { one technical subject } \\
\text { (formerly } 6 \text { years) }\end{array}$ & $\begin{array}{l}\text { Teaching certificate } \\
\text { Teachers with grade } \\
2 \text { qualification in a } \\
\text { general subject or a } \\
\text { technical subjects }\end{array}$ \\
\hline $\begin{array}{l}\text { Upper secondary } \\
\text { (grade 1) }\end{array}$ & $\begin{array}{l}\text { Teaching } \\
\text { certificate teacher } \\
\text { secondary } \\
\text { education } 2 \text { nd } \\
\text { grade }\end{array}$ & $\mathrm{HBO}$ & $\begin{array}{l}3 \text { years in one general } \\
\text { subject }\end{array}$ & $\begin{array}{l}\text { Teaching certificate } \\
\text { Teachers with grade } \\
1 \text { qualification in one } \\
\text { general subject }\end{array}$ \\
\hline
\end{tabular}




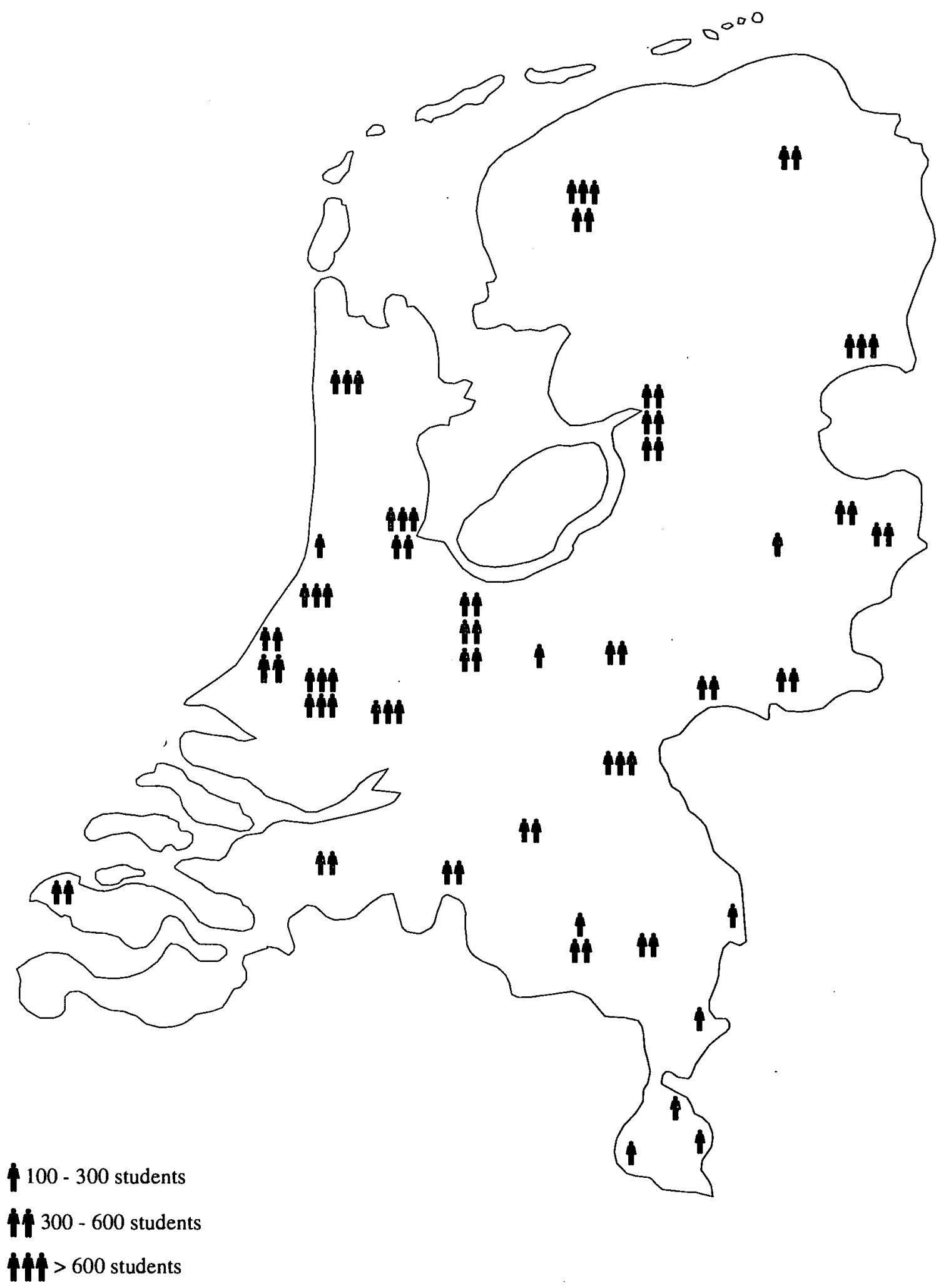

Figure 1

Teacher training institutes for primary education, 1994-1995 


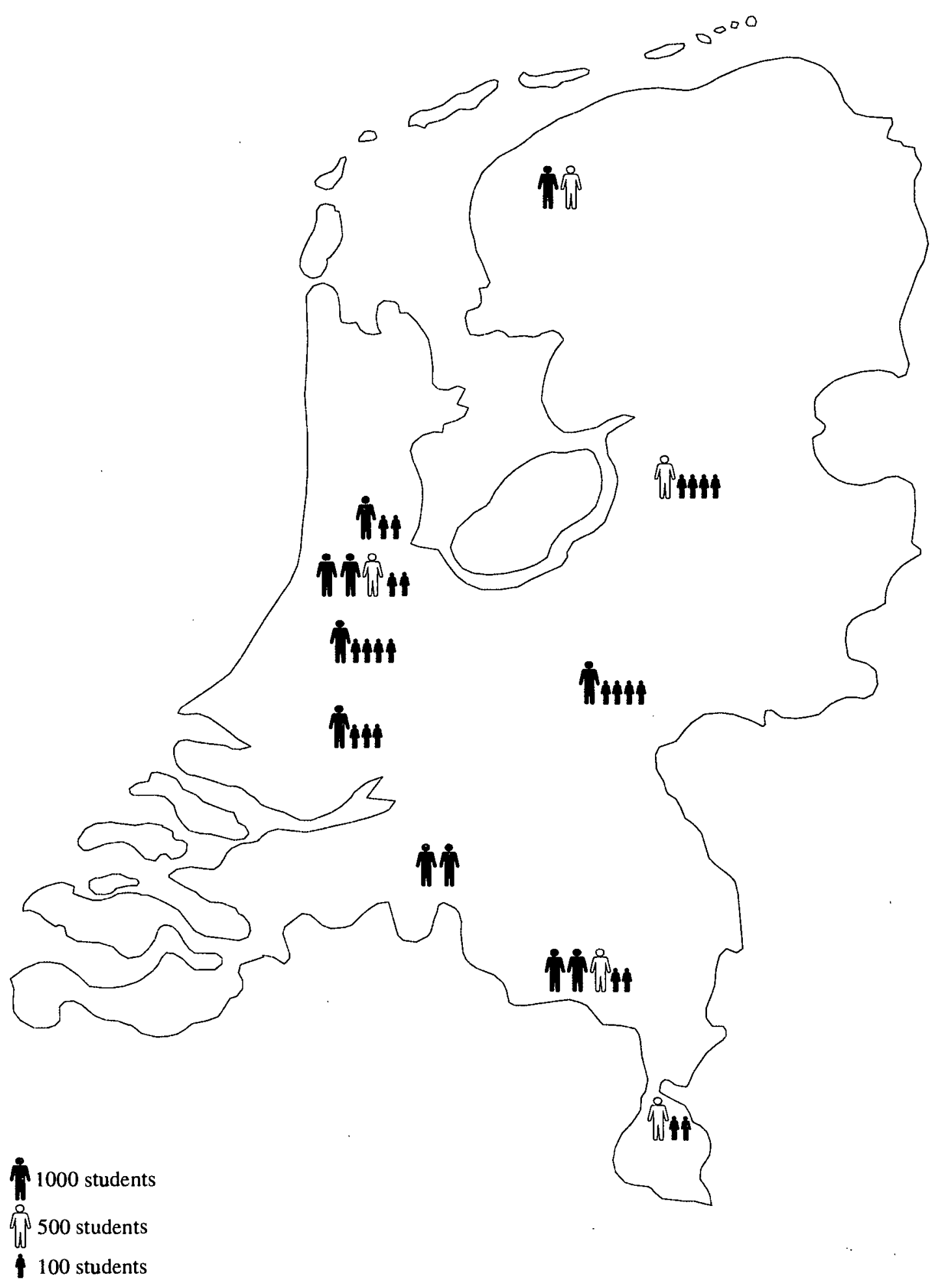

Figure 2

Teacher training institutes for secondary education (and grade, full time), 1994-1995

ERIC 60

$6^{m}$

COMMITT: Teaching and Learning for the Future 


\section{Appendix 3}

Committee Statements

\section{THE LEARNING PROCESS AND ICT}

1. Education should prepare youngsters to become full participants in today's learning society. Schools should reflect in their curricula the need for lifelong learning, to cope with rapid societal changes and the overwhelming amount of available information, a.o. by the variety of massmedia.

2. Schools have to pursue these goals in a systematic way. ICT should help to build up more powerful learning environments to support flexible planning, actual instruction and monitoring functions within the learning process.

3. The main advantage of ICT is that it can support more effective, flexible learning for every student. Every youngster has the basic right to be introduced in the information society and to benefit from ICT's motivating possibilities for the acquisition of knowledge, (basic) skills and attitudes.

4. The implementation of ICT is an important instrument in the change of the focus in the learning process from the teacher to the learner. The actual role of the teacher as a disseminator of knowledge changes into that of a manager of learning.

5. ICT helps to break down the school walls and enhances the real life quality of school learning, encourages to involve the home environment, the community and surrounding culture and even other cultures in the learning process, and helps to decrease the isolated position of the school as well as the classroom within the school.

\section{INSTITUTIONAL CONDITIONS}

1. Connectivity

Both inter- and intra-connectivity needed (providing both location and time independence):

1a. Every educational institute (all levels) needs an intra connectivity infrastructure (LAN + Web site)

1b. These local intranets need to be interconnected via Internet technology, in principle private or public. Public is recommended because (i) access of non-educational Internet as free extra and (ii) existing Internet infrastructure can be used (thus reducing costs).

Of course necessary security management tools need to be provided

- access authentication

- parental/pedagogical control program on external web access

1c. Remote Access Services in order to provide distant learning and working facilities Goals:

- Publishing of and providing access to information

Interpersonal/intergroup communication (email)

2. People

2a. Students need to experience in the school a 'natural' reflection of ICT in the society (integrated in all aspects of their activities)

2b. Teachers need to be aware of the benefits and have a basic command of the necessary ICT tools 
- Hardware and relevant application software

- Connectivity tools such as Email, Web browser, HTML publishing

2c. School administrators need to understand the benefits and have complete buy-in on the concept and need to create critical mass among the staff

2d. Non-teaching staff is of increasingly importance to facilitate the successful integration of ICT into the learning process. Schools with enough critical mass can have this done inhouse whereas smaller institutions may need to out-source.

3. Facilities

Need to reflect the role of schools as a working place for students; this must have consequences for

- technical facilities such as wiring, flexible physical design of (class-)rooms

- support and maintenance (see non-teaching staff under people)

4. Organization

4a. Proper applications support for all aspects of the learning process (e.g. student tracking system), planning tools, evaluation tools, etc.)

4b. Guaranteed level of ICT services reflected in the personnel plan as well as a standard item in the budget

- Information specialist (content)

- technical support/maintenance (infrastructure)

5. Equities of access

Planning access to ICT resources (PCs) in the school in such a way that students not having access to home PCs and RAS get preference.

\section{PROFESSIONAL TEACHER DEVELOPMENT AND ICT}

1. Given the potentials of ICT to enhance the learning process and to contribute to solutions for the challenges education is facing, student teachers have to be learned to integrate ICT in the education field for which they are trained. This means that the knowledge and skills for integrating ICT adequately into the learning process is an aspect of the future teacher profession. The importance of this aspect of the future teacher profession makes is necessary to anticipate on this development by including core specifications for the use of ICT in the formal job qualifications for teachers.

2. ICT as an aspect of the teacher training has to be professionally oriented which means that teacher training institutes also have to incorporate ICT as a medium for teacher students to enhance their knowledge in learning theories as well as their organizational skills to arrange optimal learning conditions in the education field for which they are trained. ICT-didactic and practice must be explicitly integrated in the curriculum of the teacher training institutes.

3. The teacher trainers must be personal users of ICT both in their preparation practice and in their teaching activities. The teacher trainers have to demonstrate in their own lessons for the student teachers how to integrate ICT in the learning process (teach as you preach).

4. To develop the medium-use of the technology, it is necessary that the teacher trainers are integrated in a national network. This network should explicitly aim at developing 
knowledge about ICT as a medium and the use of it in the mentioned fields in teacher training.

5. It is essential that the structure of the teaching education has to change to cope with the challenge it is confronted with in the information society. To enhance the competence in the ICT-implementation there is a need for a strong national network for educational ICT-didactics and implementation of ICT in schools. This network could be established on the basis of specifically appointed expert-institutions among the teacher training institutions. (Reference to the Norwegian network for higher education.) The appointed institutions should aim at the following fields of work:

- Learning materials. Also should they be responsible for contributing to the broader field of development of learning material for the ICT-implementation. This work calls for a team of experts, teachers, program-designers, technicians and didactic experts.

Further education and in service training can play a part of the collaboration if the teacher trainer is capable of giving valuable courses enabling the teacher to develop her teaching practice, not only her knowledge about modern technology. This kind of collaboration has to be firmly integrated in the both economical and infrastructural conditions of the teacher training institutions.

- Equipment. To enable the teacher training institutions to play this important role in a national ICT-collaboration, they have to be adequately equipped when it comes to technology. This means that the connectivity between the teacher training institutions are of utmost importance as a starting point.

\section{GOVERNMENT}

1. Government should provide leadership for the transformation process - examples of demonstrating leadership are:

a. ICT should be part of each teachers responsibility and therefore has to become an integral part of the curriculum of all teacher training institutes.

b. Define a core program for the use of ICT in the learning process.

2. Government should establish a national school data network

3. The first follow-up program should be like a national challenge program for innovative practices.

- nothing for nothing

- minister and headmasters

- voluntary participation, but a pre-requisite for funds

- years

- challenges/competition

- emergent practices project

4. Evaluation of the present situation is necessary focusing on which forces may enhance the learning process with ICT and what are the blockades for implementing ICT in the learning process. 


\section{Appendix 4}

Statements developed and judged by ICT-coordinators

Agree - Disagree Statements

1. An important advantage of ICT is that it makes a more effective and flexibele way of learning possible for students.

2. A vision on teaching and learning is necessary to be able to determine the role of ICT in this process.

3. ICT is a useful tool to get the teacher out of the isolation of the classroom and the school.

4. The COMMITT recommendations should be included in the core curriculum (70\%) of the teacher training institutes.

5. The establishment of an experimental teacher training institute is an important means the design the education of the future.

6. The COMMITT-report pays too much attention to cognitive skills and too little to social, cultural and motorial skills.

7. The management of the institutes has, beside the teachers, a key role in the process of change.

compl.

compl.don't

disagree disagree

agree agree know

8. Teacher training institutes are capable to make the change from 'old' to 'new' all by temselves.

9. Regional centres for 'learning technology' can only function properly by co-operating with the schools of primary and secondary education.

10. ICT should get an organic place within the teaching didactics.

11. The existing education support instiututes should be closely involved in the execution of the COMMITT program.

12. The regional expertise centres should not form a new institutional layer in the education system, but should be embedded in the existing structures.

13. The two proposed 'ways' of the program (care and courage) will frustrate the process of change and will lead to 'escape' behaviour.

14. It is important that the role of the teacher changes from the traditional teacher (transfer of knowledge) to the new teachers (assisting and facilitating the learning process).

15. The change toward student oriented education requires huge investments in infrastructure, professionalisation and management. 


\begin{tabular}{lllll}
\hline & $\begin{array}{c}\text { not } \\
\text { important }\end{array}$ & $\begin{array}{l}\text { hardly rather } \\
\text { important important }\end{array}$ & $\begin{array}{l}\text { very } \\
\text { important know }\end{array}$ \\
\hline
\end{tabular}

16. Facilities for communicaton (e.g. e-mail) between teachers (within and across schools) are necessary for further professionalisation of the teaching profession.

17. Stimulation of ICT in education should not be unrelated to other policy developments, but consitute an integral part of these developments.

18. The role of the management of the teacher training institutes should be made more clear in the program of action.

19. COMMITT should convince the management of the teacher training institutes that the ICT co-ordinator should not be the the ones carrying the load of the process of change.

20. Teachers of teacher training institutes are often too less informed about the possible applications of ICT: exchange of information should be stimulated.

21. The program of action should combine the apporaches from 'top-down' and 'bottom-up'.

22. In the phase of execution, there should be a link between the teacher training institutes on the one hand and the schools for primary and secondary education on the other.

23. The description of the learning process in the COMMITT-report (figure 3, page 10) is a useful conceptualisation for the determination of the possible role of ICT in education.

24. Talking about a 'program' and not about a structured and predetermined method of working offers freedom and the possibilities to stress the distinctive features of individual teacher training institutes.

25. The regional expertise centres should become a virtual reality instead of a physical one.

The numbers in the column give the percentages of respondents that ticked this category $(n=43)$. Only the highest percentages per statement are included. 


\section{Appendix 5}

\section{Different types in use of ICT as a medium}

The use of ICT as a medium often refers to a computer as a tool with some useful capability programmed into it, so called applications such as statistical analysis or word processing. Students and teachers can then use it to help them at a variety of activities for different subjects. Below we present a classification of applications using a distinction between user orientation: learner-use oriented and teacher-use oriented tools (Collis, 1992 ${ }^{1}$ ).

\section{Learner-Use Oriented}

a. Structured, predetermined learning task:

- Educational games

- Simulations

- 'Problem solving' software

b. Educational environment, tailored to a particular learning task or content but allowing flexible ways of use:

- Simulations (including varieties of 'microworlds')

- Problem solving software

- MBLs (Microcomputer-Based Laboratory materials)

- Electronically organized data sets (in relational data bases or hypertext-linked stacks, or 'electronic books', some varieties; any of these data sets may be text-only or multimedia)

- Expert systems

c. Tools or content-free environments, used for educational purposes:

- Writing environments, including word processing, desktop publishing, and other writing aids

- Data base environments (not already organized around a particular topic or goal, as in category ' $b$ ' above; may be on-line or resident in local computer or in local external storage)

- Calculation and statistical software (including spreadsheets)

- Programming environments (particularly Logo)

- Telecommunications-mediated communication environments (including those for messaging, bulletin boards, and computer conferencing)

- Electronic environments for visual and audio production and manipulation (including environments for graphing mathematical functions as well as environments for supporting creative visualisations and compositions)

- 'Cognitive tools' (such as cognitive mapping, idea organisers, and some varieties of other types of software such as expert systems if their function is, in a constructivistic way, to extend cognitive functioning during learning)

d. The use of a computer as tutee, which involves programming the computer. The computer is used to help the students order their thoughts or help them develop problem solving skills. An example of this sort of use is the programming language LOGO.

${ }^{1}$ Collis, B.A. (1992). Technology enriched schools: nine case studies with reflections. International Society for Technology in Education. 
a. Teacher productivity tools, also tools for resource acquisition and handling and for communication:

- All of the tool-categories noted above for learner use, plus:

- Student management and record-keeping software (for various types of data including individual student performance records and data for accumulation in system-wide administrative information systems)

- Software for production of specialised types of learning material (ranging from print materials such as puzzles or tests from test banks to the production of demonstration materials such as transparencies for the overhead projector or multi-media materials for presentations)

The introduction of (tele)communication technology add another dimension, namely the simultaneity in presence of teacher and learner. This is a reason to make a distinction between conventional education and distance education.

Conventional education includes all learning situations in which teacher and students are physically in the neighbourhood of each other. Therefore the voice of the teacher is the primary means of communication and therefore teaching is a 'service' which is 'produced' and 'consumated' at the same time.

Distance education, encloses all learning situations in which there is a separation between the teacher and the students. Because of this separation the communication has to go mechanically or electronically. In this form, the teaching process can be 'consummated' at a different time and place then where it is 'produced'. And to reach the students it must be packed, transmitted, stored and delivered. Differently from conventional education, the interaction between the teacher and the students can strongly be influenced by long delays. There are many possibilites for the use of telematica in education (electronic-mail, teleconferencing, telelearning, bulletin boards, news and topic services, customized educational environments, electronic libraries, Internet, etc.), but actual implementation is very limited.

From a more technological perspective a distinction is often made between information technology (which can also involve telematica) and multimedia. De term multimedia is used in case a combination of text, images and sound is tied together by a computer system. 

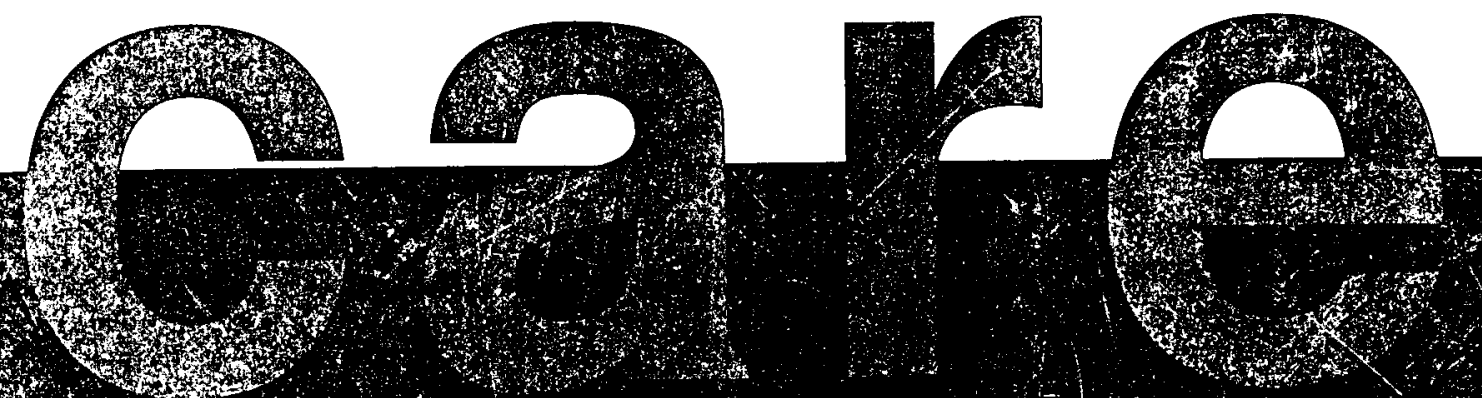

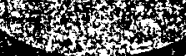

(2)

.

\section{(t) \\ to}

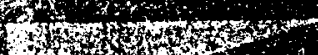
(n)

\section{5}

\%

.

$\rightarrow$ rod

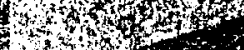

\section{\%}

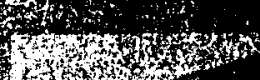

(3)

tint

4

(4)

$x+2 x+40$

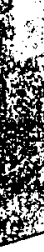

rento

x

rint

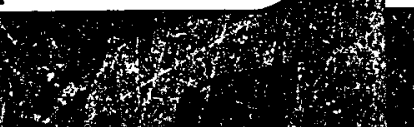

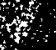
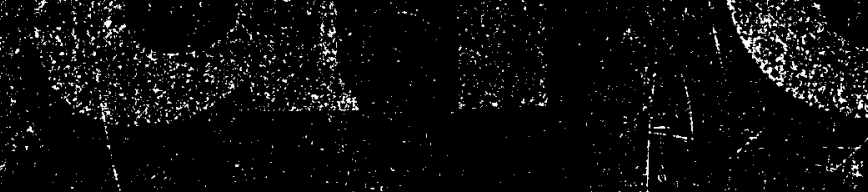

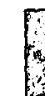

Sow

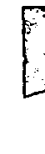

-

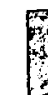

(16)

54

17x+y

\section{ERIC BESTCOPY AVRILABLE}




\section{DOCUMENT IDENTIFICATION:}

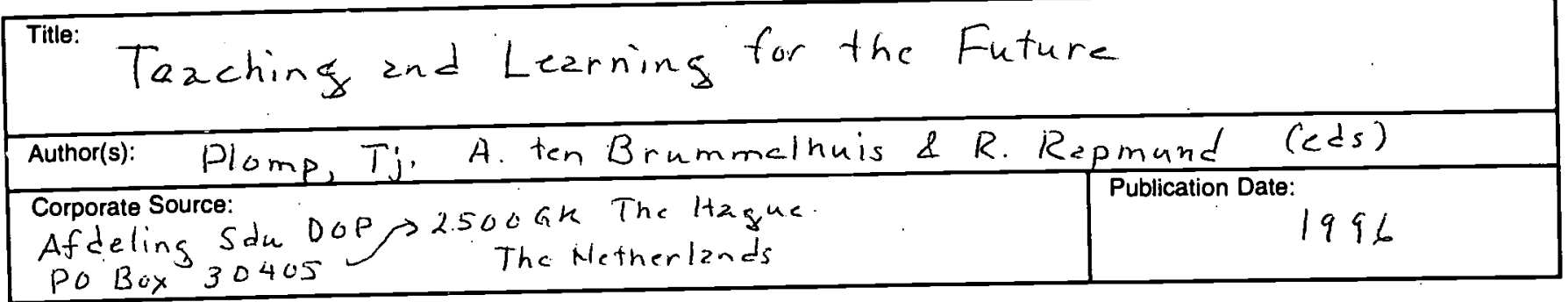

\section{REPRODUCTION RELEASE:}

In order to disseminate as widely as possible timely and significant materials of interest to the educational community, documents announced in the monthly abstract journal of the ERIC system, Resources in Education (RIE), are usually made available to users in microfiche, reproduced paper copy, and electronic/optical media, and sold through the ERIC Document Reproduction Service (EDRS) or other ERIC vendors. Credit is given to the source of each document, and, if reproduction release is granted, one of the following notices is affixed to the document.

If permission is granted to reproduce the identified document, please CHECK ONE of the following options and sign the release below.

\section{Sample sticker to be affixed to document}

\section{Check here}

Permitting microfiche (4" $\times 6^{n}$ film), paper copy, electronic, and optical media reproduction.
“PERMISSION TO REPRODUCE THIS MATERIAL HAS BEEN GRANTED BY

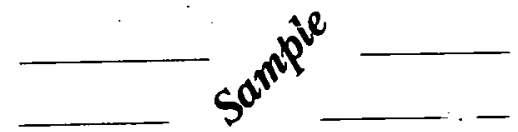

TO THE EDUCATIONAL RESOURCES INFORMATION CENTER (ERIC)"

Level 1

Sample sticker to be affixed to document

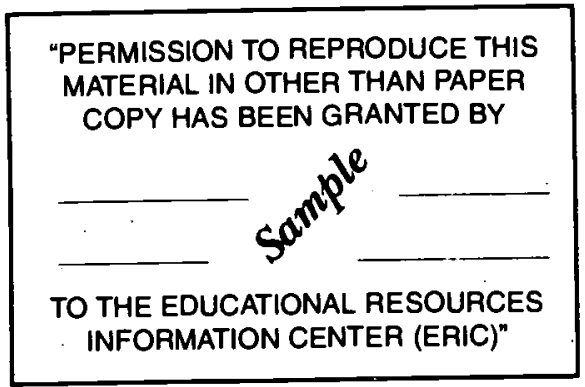

Level 2

\section{Sign Here, Please}

Documents will be processed as indicated provided reproduction quality permits. If permission to reproduce is granted, but neither box is checked, documents will be processed at Level 1.

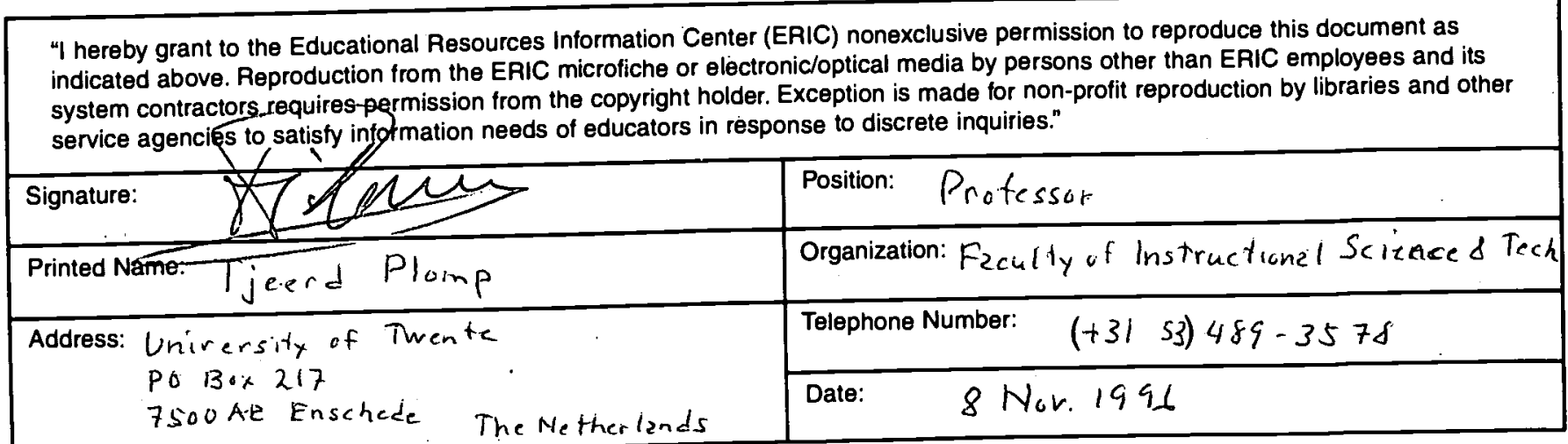

